\title{
EFFECT OF CRYOPRESERVATION PROTOCOL ON POST-THAW CHARACTERISTICS OF STALLION SPERMATOZOA
}

\author{
A Thesis \\ by \\ JOSE L. SALAZAR \\ Submitted to the Office of Graduate Studies of \\ Texas A\&M University \\ in partial fulfillment of the requirements for the degree of \\ MASTER OF SCIENCE
}

August 2009

Major Subject: Veterinary Medicine 


\title{
EFFECT OF CRYOPRESERVATION PROTOCOL ON POST-THAW CHARACTERISTICS OF STALLION SPERMATOZOA
}

\author{
A Thesis \\ by \\ JOSE L. SALAZAR \\ Submitted to the Office of Graduate Studies of \\ Texas A\&M University \\ in partial fulfillment of the requirements for the degree of \\ MASTER OF SCIENCE
}

\begin{abstract}
Approved by:
Chair of Committee, Dickson D. Varner

Committee Members, Charles C. Love

Steve P. Brinsko

David W. Forrest
\end{abstract}

Head of Department, William Moyer

August 2009

Major Subject: Veterinary Medicine 


\begin{abstract}
Effect of Cryopreservation Protocol on Post-Thaw Characteristics of Stallion Spermatozoa. (August 2009)

Jose L. Salazar, B.S., Texas A\&M University

Chair of Advisory Committee: Dr. Dickson D. Varner
\end{abstract}

Three ejaculates from each of eight stallions were initially centrifuged in INRA 96 extender and spermatozoal pellets were resuspended in a milk/egg yolk-based freezing extender or an egg yolk-based freezing extender. Extended semen was exposed to a fast pre-freeze cooling rate (FAST - semen immediately subjected to cryopreservation) or a slow pre-freeze cooling rate (SLOW - semen pre-cooled at a controlled rate for 80 minutes prior to cryopreservation). After thawing, semen was diluted in initial freezing medium (FM) or INRA 96 prior to analysis of 9 experimental endpoints: total motility (MOT; \%), progressive motility (PMOT; \%), curvilinear velocity (VCL; $\mu \mathrm{m} / \mathrm{sec}$ ), average-path velocity (VAP; $\mu \mathrm{m} / \mathrm{sec}$ ), straight-line velocity (VSL; $\mu \mathrm{m} / \mathrm{sec}$ ), linearity (LIN; \%), intact acrosomal and plasma membranes (AIVIAB; \%), intact acrosomal membranes (AI; \%), and intact plasma membranes (VIAB; \%). Eight of nine experimental endpoints (MOT, PMOT, VAP, VSL, LIN AIVIAB, AI, and VIAB) were affected by extender type, with LE extender yielding higher values than MF extender for these variables $(\mathrm{P}<0.05)$. Exposure of extended semen to a slow pre-freeze cooling period resulted in increased values for seven of nine endpoints, as compared to a 
fast pre-freeze cooling period $(\mathrm{P}<0.05)$. Mean VAP and VSL were unaffected by prefreeze cooling rate $(\mathrm{P}>0.05)$. As a post-thaw diluent, INRA 96 yielded higher mean values than FM for MOT, PMOT, VCL, VAP, and VSL $(\mathrm{P}<0.05)$. Treatment group FM yielded slightly higher values than INRA 96 for LIN and VIAB $(\mathrm{P}<0.05)$. Extender $\mathrm{x}$ rate interactions $(\mathrm{P}<0.05)$ were detected for the variables MOT, AIVIAB, AI and VIAB. Mean values for these endpoints were higher following spermatozoal exposure to a slow pre-freeze cooling period, regardless of freezing extender type $(\mathrm{P}<0.05)$. The effects of pre-freeze cooling rate on MOT, AIVIAB, AI, and VIAB were more pronounced in spermatozoa cryopreserved in MF extender, as compared to LE extender. Within treatment groups SLOW and FAST, mean MOT, AIVIAB, AI, and VIAB were higher $(\mathrm{P}<0.05)$ for spermatozoa cryopreserved in LE extender, as compared to MF extender. Extender $\mathrm{x}$ diluent interactions $(\mathrm{P}<0.05)$ were detected for MOT, PMOT, VCL, VAP, VSL, and LIN. Within Group MF, mean MOT, PMOT, VCL, VAP, and VSL were higher in INRA diluent, as compared to FM diluent $(\mathrm{P}<0.05)$. Within Group LE, FM diluent yielded slightly higher values than INRA diluent for PMOT, VAP, VSL, and LIN $(\mathrm{P}<0.05)$. In conclusion, a slow pre-freeze cooling rate was superior to a fast prefreeze cooling rate, regardless of freezing extender used, and INRA 96 served as a satisfactory post-thaw diluent prior to semen analysis. 


\title{
DEDICATION
}

\author{
I dedicate this work to: \\ My parents: Olga and Luis Salazar, \\ Dr. Clint Kainer \\ $\&$
}

My family and friends.

These loved ones provided me with a stable foundation that has allowed me to live my dreams and accomplish lifelong goals that would have been impossible otherwise. Without them I would not be the man I am today nor the one I continue to mold into. Mom and Dad, thank you for always affording me with everything I needed to succeed. Clint, thanks for giving me the opportunity to learn and gain priceless experiences by shadowing you over the years. You have all had many appreciated and respectable impacts throughout my life and career. Thank You! 


\section{ACKNOWLEDGEMENTS}

I would like to thank Drs. Varner, Love, Brinsko, and Forrest for their guidance throughout my research. Dr. Varner, I am grateful for the opportunity you provided me with by allowing me to work under your supervision as a graduate student. Your expertise, guidance, and charisma have made this experience a very enjoyable one. Dr. Love, thank you for your time, patience, knowledge, and willingness to help on short notice. It was always greatly appreciated. Dr. Brinsko, thank you for your guidance and spectacular teaching ability. Your knowledge and expectations made learning interesting. Dr. Forrest, your guidance and willingness to help was greatly appreciated. Dr. Brian Miller, thank you for your constant enthusiasm to help at any time and for teaching me throughout the process. I also appreciate the collaborative efforts of the TAMU College of Veterinary Medicine, Equine Theriogenology Laboratory for helping me with the numerous semen collections. Sheila, Kat, thank you for the wonderful help and companionship you provided me with throughout this endeavor. Jessie, thank you for all your help as well. Your wonderful contribution will always be remembered. Katie and Ann, thanks for your assistance on the project also. I am greatly appreciative of everyone and feel privileged to have met and worked with all of you. Thank you! 


\section{TABLE OF CONTENTS}

Page

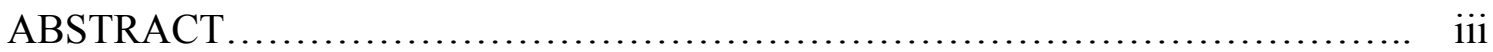

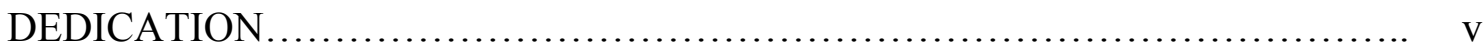

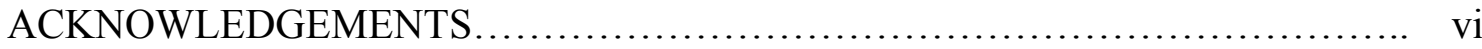

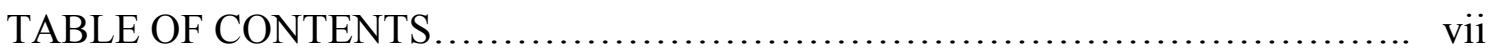

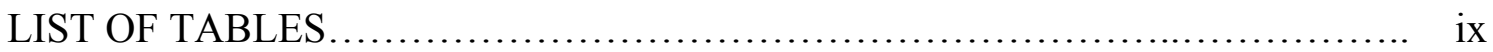

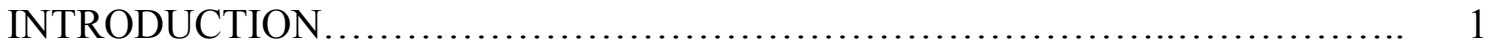

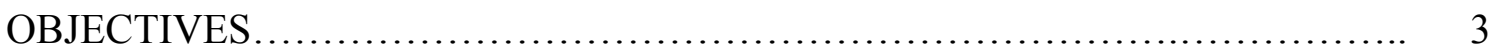

LITERATURE REVIEW ................................................... 4

Freezing Extenders............................................... 4

Cooling Rates....................................................... 6

Glycerol Concentration............................................. 8



Post-thaw Diluent..................................................... 11

MATERIALS AND METHODS......................................... 12

Semen Collection and General Processing.............................. 12

Spermatozoal Cryopreservation Procedures........................... 13

Computer-Assisted Sperm Motion Analysis (CASMA)....................... 15

Sperm Chromatin Structure Assay ................................... 16

Evaluation of Sperm Acrosomal and Plasma Membrane

Integrity......................................................... 17

Statistical Analysis................................................ 18 
RESULTS.................................................................... 20

DISCUSSION AND SUMMARY .......................................... 44

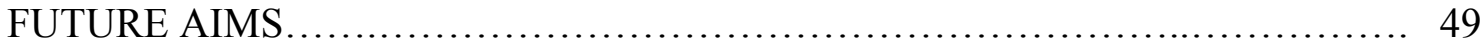

REFERENCES........................................................... 50

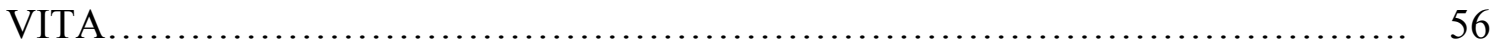




\section{LIST OF TABLES}

TABLE

Page

1 Main effects of extender, rate, and diluent on mean $( \pm \mathrm{SD})$ value of spermatozoal motility, viability, acrosomal intactness, and chromatin quality.

2 Effects of pre-freeze cooling rate on mean $( \pm \mathrm{SD})$ value of spermatozoal motility, viability, acrosomal intactness, and chromatin quality as sorted by extender type

3 Effects of extender type on mean $( \pm \mathrm{SD})$ value of spermatozoal motility, viability, acrosomal intactness, and chromatin quality as sorted by pre-freeze cooling rate.

4 Effects of post-thaw diluent on mean $( \pm \mathrm{SD})$ value of spermatozoal motility, viability, acrosomal intactness, and chromatin quality as sorted by extender type....

5 Effects of post-thaw diluent on mean $( \pm \mathrm{SD})$ value of spermatozoal motility, viability, acrosomal intactness, and chromatin quality as sorted by pre-freeze cooling rate

6 Correlation coefficients and p-values among 10 dependent variables over all treatments (all data; $\mathrm{N}=168$ ) and for semen exposed to LE extender, a slow pre-freeze cooling rate, and using INRA 96 as a postthaw diluent $(\mathrm{N}=22)$

7 Comparison of values (Mean, S.D., Minimum, Maximum) for dependent variables for the complete post-thaw dataset which included all treatments $(\mathrm{N}=168)$ and the post-thaw dataset selected to optimize post-thaw spermatozoal quality (LE / SLOW / INRA postthaw dataset; $\mathrm{N}=22$ ).... 
8 Correlation coefficients and p-values to determine effect of pre-freeze motility and chromatin values (TO, T24, and DIFF) on post-thaw measures of semen quality following spermatozoal exposure to LE or MF extender, a SLOW or FAST pre-freeze cooling rate, and INRA 96 or FM diluent $(\mathrm{N}=168)$

9 Correlation coefficients and p-values to determine effect of pre-freeze motility and chromatin values (TO, T24, and DIFF) on post-thaw measures of semen quality following spermatozoal exposure to LE extender, a SLOW pre-freeze cooling rate, and INRA 96 diluent $(\mathrm{N}=22)$.

10 Correlation coefficients and p-values for fresh semen total motility (T0-MOT; \%) and post-thaw semen measures for stallion spermatozoa.

11 Correlation coefficients and p-values for fresh semen progressive motility (T0-PMOT; \%) and post-thaw semen measures for stallion spermatozoa.

12 Correlation coefficients and p-values for fresh semen curvilinear velocity (T0-VCL; $\mu \mathrm{m} / \mathrm{s})$ and post-thaw semen measures for stallion spermatozoa.

13 Correlation coefficients and p-values for fresh semen chromatin (T0-COMP; \%) and post-thaw semen measures for stallion spermatozoa.

14 Correlation coefficients and p-values for cooled semen total motility (T24-MOT; \%) and post-thaw semen measures for stallion spermatozoa. 
15 Correlation coefficients and p-values for cooled semen progressive motility (T24-PMOT; \%) and post-thaw semen measures for stallion spermatozoa...........................................................

16 Correlation coefficients and p-values for cooled semen curvilinear velocity (T24-VCL; $\mu \mathrm{m} / \mathrm{s}$ ) and post-thaw semen measures for stallion

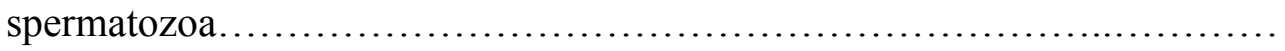

17 Correlation coefficients and p-values for cooled semen chromatin (T24-COMP; \%) and post-thaw semen measures for stallion spermatozoa...........................................................

18 Correlation coefficients and p-values for fresh/cooled semen total motility \% change (DIFF-MOT; \%) and post-thaw semen measures for stallion spermatozoa...............................................

19 Correlation coefficients and p-values for fresh/cooled semen progressive motility \% change (DIFF-PMOT; \%) and post-thaw semen measures for stallion spermatozoa...

20 Correlation coefficients and p-values for fresh/cooled semen curvilinear velocity $\%$ change (DIFF-VCL; $\mu \mathrm{m} / \mathrm{s}$ ) and post-thaw semen measures for stallion spermatozoa...

21 Correlation coefficients and p-values for fresh/cooled semen chromatin \% change (DIFF-COMP; \%) and post-thaw semen measures for stallion spermatozoa. 


\section{INTRODUCTION}

With the rapid growth of the equine breeding industry, the use of frozen semen has become more common in order to preserve superior genetics as well as sustain a successful breeding program. Some of the benefits of using cryopreserved semen include access to semen from stallions standing abroad and from those involved in competition. Perhaps one of the major advantages with the availability of frozen semen is that breeders can more easily inseminate a mare at the optimal breeding time instead of having to rely on the availability of stallion semen. Unfortunately, the success of cryopreservation with stallion spermatozoa is generally considered to be lower than that of some other domestic species, especially that of dairy cattle. The overall reduced fertility of cryopreserved stallion semen, as compared to cooled or fresh semen, is disadvantageous to both stallion and mare owners. The reason for this reduction in fertility is likely due to the fact that stallions are most commonly selected as sires based on performance record, pedigree, and conformation, as opposed to fertility. Researchers have developed and tested many extenders and freezing techniques over the years in an effort to improve the post-thaw quality of stallion spermatozoa. Nonetheless, there has not been a major break through with the cryopreservation of stallion spermatozoa that has drastically enhanced post-thaw semen quality of stallions.

This thesis follows the style of Theriogenology. 
The purpose of this experiment was to identify which of two commonly used commercial cryopreservation extenders for stallion semen produces the best post-thaw semen quality following two different pre-freeze cooling techniques. The two extenders used were the E-Z Freezin ${ }^{\circledR}$ "MFR5" extender (MFR5) and E-Z Freezin® "LE” extender (LE). Semen in either extender was exposed to a fast or a slow pre-freeze cooling process. The effect of post-thaw diluent on a variety of laboratory endpoints was also studied. 


\section{OBJECTIVES}

The objectives of this study were to determine the effects of cryopreservation extender type and pre-freeze cooling period on post-thaw semen quality in stallions, based on an array of laboratory measures. The effect of post-thaw semen diluent on semen quality was also tested. Determining an overall superior treatment may lessen the need for testing various freezing extenders and pre-freeze cooling rates among individual stallions. With this study, we hope to discover a treatment providing superior results that may be suggested as an optimal cryopreservation protocol across a range of stallions. 


\section{LITERATURE REVIEW}

\section{Freezing Extenders}

Over the years researchers have tested and proposed numerous freezing extenders of various compositions in attempt to improve the quality and use of frozen stallion semen. Comparisons among stallion freezing extenders are documented poorly [1]. It has also been reported that the most effective semen extender for one stallion is not necessarily the most effective for another [2]. In 1984, Palmer indicated that freezing horse semen could use the same milk diluents (used for diluting semen immediately after collection) with the addition of $2 \%$ egg yolk and $2.5 \%$ glycerol [3]. In this study, he concluded that the milk + sugar + citrate freezing media proved to be significantly higher in regards to post-thaw motility compared to milk alone and HF20 extenders [3]. The composition of this extender resulted in the formation of the milk based Modified French formula freezing extender (MFR5) that is used commercially today for freezing equine spermatozoa. The Lactose EDTA (LE) freezing extender is another commercially used equine freezing extender that is egg-yolk based. The composition of this extender developed by Martin et al. in 1979 was an experimentally developed extender formulated by combining two extenders; lactose and EDTA. Lactose EDTA resulted in higher post-thaw progressive motility $(53.4 \%)$ when compared to the control (42.3\%) which was composed of lactose, egg yolk, and glycerine [4]. In a study conducted by Ecot et al. in 2000, a variety of extenders along 
with cooling treatments were tested in attempt to determine the effects of different cooling treatments and semen extenders on spermatozoal samples from individual stallions. The extenders used in this study were INRA82, Kenney, and Gent. The INRA82 and Kenney extenders are similar and all three contain milk. Different concentrations of egg yolk ( 2 or $4 \%$ ) and glycerol $(2.5$ or $3.5 \%)$ were applied to the INRA and Kenney extenders in experiment 2. Ecot et al. concluded that modification of egg yolk and glycerol concentrations resulted in higher spermatozoal motility in samples frozen in Kenney extender than in INRA82 extender [5]. As a result of experiment one where all three extenders were compared, several stallions had the same motility across all three, whereas some stallions had better motility when their semen was frozen in Kenney extender [5]. It was indicated that the experiments did not clearly establish differences in tolerance to semen extender among stallions.

Only a few comparisons have been made among freezing extenders for freezing stallion spermatozoa [1,5-9]. Results concluded that, although Kenney FE extender yielded higher motility compared to Lactose-Glucose EDTA and INRA82 FE extenders, it also produced a higher percentage of acrosome-reacted and capacitated spermatozoa thus resulting in lower per cycle pregnancy rate [10].

One of the important components of freezing extenders is egg yolk. The concentration of egg yolk varies in different extenders used and has been studied as well. Vidament et al. found that increasing egg yolk from 2 to $4 \%$ did not improve post-thaw 
motility [11]. The results of their particular experiment were consistent with similar results of frozen semen by Ecot et al. in 2000 [5,11]. Ecot et al. suggested that the concentration of egg yolk likely depends upon the extender used and the level of glycerol and milk [5].

\section{Cooling Rates}

The major damage to spermatozoa as a result of cold shock is dependent upon the final temperature before freezing as well as the cooling speed until that temperature is reached. The results of cold shock are characterized by abnormal motility patterns, rapid loss of motility, and membrane damage [12]. Kayser et al. reported that spermatozoa could be rapidly cooled from 37 to $20^{\circ} \mathrm{C}$ but required a linear cooling rate of -0.05 to $-0.1^{\circ} \mathrm{C} / \mathrm{min}$ between 20 and $5^{\circ} \mathrm{C}$ to maximize spermatozoal motility [13]. In a study conducted by Moran et al. the temperature range demonstrating when stallion spermatozoa were most susceptible to cold shock was between 19 and $8^{\circ} \mathrm{C}$ [12]. As a result the cooling rates recommended for extended semen are as follows 1) rapid from 37 to $19^{\circ} \mathrm{C}\left(-0.7\right.$ to $\left.\left.-2^{\circ} \mathrm{C} / \mathrm{min}\right) 2\right)$ slow from 19 to $8^{\circ} \mathrm{C}\left(-.05\right.$ to $\left.-.1^{\circ} \mathrm{C} / \mathrm{min}\right)$ and 3$)$ rapid from 8 to $4^{\circ} \mathrm{C}\left(-.7^{\circ} \mathrm{C} / \mathrm{min}\right)$ [12]. Vidament et al. performed a study which incorporated a freezing rate of $37^{\circ} \mathrm{C}$ to $4^{\circ} \mathrm{C}$ in 1 hour [14]. The cooling rates ranged from -4 to $2^{\circ} \mathrm{C} / \mathrm{min}$ between 37 and $22^{\circ} \mathrm{C},-0.4^{\circ} \mathrm{C} / \mathrm{min}$ between 20 and $10^{\circ} \mathrm{C}$, then $-0.2^{\circ} \mathrm{C} / \mathrm{min}$ between 10 and $8^{\circ} \mathrm{C}$ [14]. After cooling, semen was maintained at $4{ }^{\circ} \mathrm{C}$ for 1 hour before freezing [14]. Among all of the treatments, this delayed cooling treatment resulted in the 
highest percentage of post thaw-motility. Vidament et al. recommended a procedure for freezing and thawing in INRA82 that involved cooling extended semen to $4^{\circ} \mathrm{C}$ in $1 \mathrm{~h} 20$ min, then filling straws at $4^{\circ} \mathrm{C}$, and freezing [11].

Vidament et al. showed significant results in post-thaw motility among all treatments when centrifugation and addition of glycerol was added at $22^{\circ} \mathrm{C}$ instead of $4^{\circ} \mathrm{C}[14]$. Direct freezing after centrifugation at $22^{\circ} \mathrm{C}$ resulted in lower post-thaw motility compared to cooling to $4^{\circ} \mathrm{C}$ in 1 hour before freezing [14]. This is also in agreement with reports by Heitland et al. [1,14]. Another study conducted by Crockett et al. reported that progressive motility (PMOT) for spermatozoa was higher when centrifuged before cooling (30\%) vs. after cooling (19\%) [15]. When centrifugation and addition of glycerol was performed at $4^{\circ} \mathrm{C}$, post-thaw motility was also higher when cooling from $37^{\circ} \mathrm{C}$ to $4^{\circ} \mathrm{C}$ in 1 hour vs. 4 hours [14].

Heitland et al. reported that skim milk-egg yolk-glycerol extender yielded higher total and progressive spermatozoal motility, as compared to Lactose EDTA when spermatozoa were cooled to $5^{\circ} \mathrm{C}$ over a 2.5 hour period prior to freezing rather than freezing at $20^{\circ} \mathrm{C}[1]$. In a latter study conducted by Crockett et al. to demonstrate the effects of cooling before freezing on post-thaw motility they found that samples frozen 2.5 hours after cooling to $5^{\circ} \mathrm{C}$ had higher percentages of progressive motility (27\%) vs. samples frozen 24 hours after cooling (10\%) [15]. Samples also frozen 2.5 hours after cooling in skim milk extenders containing egg yolk yielded a higher percentage of 
progressively motile spermatozoa (avg. 32\%) than skim milk alone (avg. 16\%) [15].

Crockett et al. also stated that skim milk extenders generally require a relatively slow cooling of spermatozoa to $5^{\circ} \mathrm{C}$ over 2-2.5 hours prior to freezing [15].

\section{Glycerol Concentration}

Glycerol is an essential cryoprotectant in all conventional extenders at (at concentrations of 2.5-6\%) used for freezing stallion spermatozoa [16]. In 2001, a study conducted by Vidament et al. revealed there was no overall effect of glycerol concentration on post-thaw motility, regardless of the freezing protocol, however there seemed to be differences among stallions [11]. For example, for four stallions motility tended to increase when glycerol was above $3 \%$. However, for one, motility tended to decrease as glycerol increased. Vidament et al. concluded that different glycerol concentrations (range: $1.5-4.5 \%$ ) had no significant effect on post-thaw motility although $2.4-2.8 \%$ resulted in slightly higher (nonsignificant) motility [11]. These results were similar with other studies within the same laboratory where glycerol concentrations from 0 to $5 \%$ were tested and the optimum values obtained were at 2 or 3\%. Ecot et al. also reported similar post-thaw motilities for spermatozoa frozen in INRA82 containing 2.5 and $3.5 \%$ glycerol [5]. Although increasing the glycerol concentration from 2.5 to $3.5 \%$ did not significantly increase spermatozoal motility in extenders containing $2 \%$ egg yolk, increasing the glycerol concentration in $4 \%$ egg yolk extenders did increase spermatozoal motility [5]. Cochran et al. and Cristanelli et al. 
also observed increased spermatozoal motility in Martin's extender containing 4\% glycerol versus 2 or $3 \%$ glycerol $[17,18]$. These results may indicate an interaction between egg yolk and glycerol in semen extenders. Burns and Reasner reported that the lowest concentration of glycerol in a Kenney extender that provided maximal cryoprotective effects was $2 \%$ [19]. Vidament et al. concluded based on their studies, that $2.5 \%$ glycerol in freezing extender routinely provides satisfactory per-cycle fertility [11]. In 2005, Vidament et al. recommended a glycerol concentration range from 2.5$3.5 \%$ when considering both motility and fertility [10].

The optimal glycerol concentration for maximal post-thaw motility using INRA82 extender is around $2-3 \%[5,11,20], 4 \%$ for the commonly used LactoseGlucose EDTA [17-18], and between 0 and 2\% for Kenney freezing extender [19].

\section{Spermatozoal Freezability and Fertility}

In 2005, Vidament demonstrated a relationship between motility and fertility.

The study showed a $43 \%$ pregnancy rate per cycle when motility was less than $45 \%$ and a pregnancy rate of $52 \%$ when the motility was above that value [10]. A similar relationship was found between average path velocity (VAP) and fertility as well. Pregnancy rate per cycle was $45 \%$ when VAP was $<66 \mu \mathrm{m} / \mathrm{s}$ and $54 \%$ when VAP was over this value [10]. However, no relationship was found between amplitude of lateral head displacement (ALH) and fertility. This study also yielded a high rate of selected ejaculates. They reported that $64 \%$ of stallions had more than $90 \%$ of their ejaculates 
selected after freezing for use on mares [10]. Others have obtained high freezability results as well [21-22].

Vidament et al. reported significant improvement on per cycle fertility with semen subjected to centrifugation and addition of glycerol at $22^{\circ} \mathrm{C} 10 \mathrm{~min}$ after collection [5].

There have been numerous attempts to find different post-thaw criteria to predict the fertility of frozen semen however, there are only few with a sufficient number of stallions and mares [23-24]. Nevertheless, all data support the conclusion that there is a relationship between post-thaw motility and fertility of frozen semen, at least among ejaculates frozen by the same technique and used in a similar manner [10]. However, when applying different protocols, the relationship may no longer exist because of possible variable reactions of spermatozoa with different extenders and cooling rates [10].

Vidament et al. reported that there was a strong relationship between fertility of fresh semen and semen freezability [25]. However, the relationship between fertility of frozen semen and freezability was not as marked [25].

A study by Brinsko et al. concluded that commonly used methods for assessing spermatozoal function do not appear to be useful in predicting stallion semen freezability [26]. Their results only indicated that as the percentage of progressively motile morphologically normal spermatozoa in fresh semen decreases, the percentages will be 
even lower in cooled and frozen-thawed samples. Therefore, high percentages of progressively motile spermatozoa in fresh semen samples, is not indicative of similar motility patterns in cooled and frozen-thawed samples [26]. However, the better a fresh semen sample was in terms of progressive spermatozoal motility, the better a frozenthawed semen sample would be in terms of total spermatozoal motility [26].

\section{Post-thaw Diluent}

There are limited reports on the effects of different media used as post-thaw diluents for analyzing spermatozoa. Palmer reported a significant decrease in fertility per cycle when glycerol was in the post-thaw diluent (INRA82) [3]. Some other reports of post-thaw diluents used for post-thaw motility analysis; Vidament et.al (2001) and Ecot et al. (2000) used INRA82, Cristanelli et al. (1984) used lactose EDTA egg yolk extender without glycerol, Burns and Reasner (1995) used BF extender without egg yolk or glycerol, Heitland et al. (1996) used E-Z Mixin, and Backman et al. (2004) used SMEY (skim milk egg-yolk) extender without glycerol however, no data are available $[1,5,11,18,19,27]$. 


\section{MATERIALS AND METHODS}

\section{Semen Collection and General Processing}

Twenty-four ejaculates (three from each of eight mature sexually active lightbreed stallions) were collected using an artificial vagina (Missouri-model; Nasco, Ft. Atkinson, WI, USA) equipped with an in-line nylon micromesh filter (Animal Reproduction Systems, Chino, CA, USA) to permit collection of gel-free semen. An ovariectomized mare was used for sexual stimulation and as mount source. Total spermatozoal number in gel-free semen was obtained by measuring semen volume with a graduated cylinder and measuring spermatozoal concentration photometrically (SpermaCue; Minitube of America, Inc., Verona, WI, USA). One-ml aliquots of raw (neat) semen were immediately snap frozen on dry ice in 1-ml polypropylene tubes (Cryogenic vials [1.2-ml]; Corning Life Sciences, Lowell, MA, USA) then stored at -80 ${ }^{\circ} \mathrm{C}$ until analyzed for spermatozoal chromatin susceptibility to denaturation (ie, Sperm Chromatin Structure Assay; SCSA).

An aliquot of gel-free semen was immediately diluted with a warmed $\left(37^{\circ} \mathrm{C}\right)$ milk extract-based extender (INRA96; IMV, Maple Grove, MN, USA) to a final spermatozoal concentration of 25 million spermatozoa $/ \mathrm{ml}$ for evaluation of spermatozoal motility (Time $0 ;$ T0), using a computerized spermatozoal motion analyzer (IVOS Version 12.2L, Hamilton Thorne Biosciences, Beverly, MA, USA). Aliquots of semen were also diluted with INRA 96 to a final spermatozoal concentration of $20 \times 10^{6}$ 
spermatozoa/ml, and then packaged with minimal air space in capped 5-ml polypropylene tubes (Cryogenic vials [5.0-ml]; Corning Life Sciences, Lowell, MA, USA). Prepared vials were than packaged as recommended by the manufacturer in a commercial semen transport container (EquitainerTM II; Hamilton Research, Inc., South Hamilton, MA, USA) for 24 hours of cooled storage (Time 24 h; T24). Following this storage period, aliquots of semen were subjected to frozen storage, as described above, for SCSA. Remaining semen was warmed for $15 \mathrm{~min}$ in a water bath set at $37{ }^{\circ} \mathrm{C}$ and subjected to computerized motility analysis, as described above. The percent change in values for dependent variables (MOT, PMOT, VCL, COMP) from T0 to T24 (DIFF) were also determined.

\section{Spermatozoal Cryopreservation Procedures}

Gel-free semen was diluted in INRA 96 extender to obtain a final spermatozoal concentration of approximately $50 \times 10^{6} / \mathrm{ml}$. Thirty-ml aliquots of extended semen were loaded into glass nipple-bottom centrifuge tubes (Pesce Lab Sales, Kennett Square, PA, USA). Thirty microliters of iodixanol (OptiPrep, ${ }^{\text {TM }}$ Axis-Shield, Oslo, Norway) was added beneath extended semen to provide a cushion for spermatozoa during centrifugation. Extended semen was centrifuged at $400 \mathrm{x} \mathrm{g}$ for $20 \mathrm{~min}$, followed by aspiration of supernate. The remaining spermatozoal pellet (with approximately $1 \mathrm{ml}$ of overlying supernate) was resuspended in one of two extender types; 1) E-Z Freezin ${ }^{\mathrm{TM}}$ “LE” semen extender; LE (Animal Reproduction Systems, Chino, CA, USA) or 2) E-Z 
Freezin TM _ "MFR5” semen extender; MFR5 (Animal Reproduction Systems, Chino, CA, USA) with the final spermatozoal concentration adjusted to approximately $200 \mathrm{x}$ $10^{6}$ spermatozoa $/ \mathrm{ml}$. The LE extender contained approximately $21.5 \%$ egg yolk $(\mathrm{v} / \mathrm{v})$ and no milk products. The MFR5 extender was a milk-based product, containing approximately $3 \%$ egg yolk $(\mathrm{v} / \mathrm{v})$. The glycerol concentration was adjusted to $2.5 \%$ $(\mathrm{v} / \mathrm{v})$ in each extender. Freezing extenders were stored frozen at $-80^{\circ} \mathrm{C}$ until used. Prior to use, thawed extenders were centrifuged at $1500 \mathrm{x}$ g for $15 \mathrm{~min}$. The supernate was harvested aseptically and passed through $5-\mu \mathrm{m}$ and 1.2- $\mu \mathrm{m}$ pore size nylon filters (GE Osmonics, Minnentonka, MN, USA) in tandom. These procedures were performed to eliminate particulate matter in the freezing extenders that might otherwise interfere with computerized spermatozoal motion analysis.

Semen diluted in each freezing extender was loaded into appropriately labeled 0.5-ml capacity straws and subjected to one of two pre-freeze cooling periods: 1) fast pre-freeze cooling rate, whereby a static vapor freeze was implemented within 5 min. following straw loading, with the freeze cycle beginning at approximately $25^{\circ} \mathrm{C}$ (FAST), and 2) slow pre-freeze cooling rate, whereby loaded straws were slowly cooled in the chamber of a programmable liquid nitrogen cell freezer (CBS Freezer 2100 Series; Custom Biogenics Systems, Shelby Township, MI, USA; SLOW). The chamber cooling ramps were $-2.0{ }^{\circ} \mathrm{C} / \mathrm{min}$ from approximately $25^{\circ} \mathrm{C}$ to $22^{\circ} \mathrm{C} ;-0.3{ }^{\circ} \mathrm{C} / \mathrm{min}$ from $22{ }^{\circ} \mathrm{C}$ to 
$10^{\circ} \mathrm{C}$; and $-0.2^{\circ} \mathrm{C} / \mathrm{min}$ from $10^{\circ} \mathrm{C}$ to $4^{\circ} \mathrm{C}$. The total cooling time for Group SLOW was approximately 80 min. For Groups FAST and SLOW, semen-filled straws were frozen 4 $\mathrm{cm}$ above a liquid nitrogen bath for $15 \mathrm{~min}$, and then plunged into liquid nitrogen for storage.

For analysis, straws were thawed by submersion for $30 \mathrm{~s}$ in a water bath set at 37 ${ }^{\circ} \mathrm{C}$. Thawed semen was further diluted (semen:extender ratio of $1: 9[\mathrm{v} / \mathrm{v}]$ ) in one of two extenders: 1) INRA 96 extender (INRA96) or 2) the freezing extender used for cryopreservation (FM). Individual aliquots of prepared semen samples were subjected to computerized analysis of spermatozoal motion following incubation at $37^{\circ} \mathrm{C}$ for 15 min; frozen in 1-ml vials for SCSA, and subjected to flow cytometric evaluation of spermatozoal acrosomal integrity and plasma membrane integrity.

\section{Computer-Assisted Sperm Motion Analysis (CASMA)}

Spermatozoa were analyzed by CASMA, in a manner similar to that previously described [28]. A 6- $\mu$ l aliquot of extended semen was placed in a warmed $\left(37^{\circ} \mathrm{C}\right)$ counting chamber with a fixed height of $20 \mu \mathrm{m}$ (Leja Standard Count 2 Chamber slides; Leja Products, B.V., Nieuw-Vennep, The Netherlands). The slide was then placed on a stage set at $37{ }^{\circ} \mathrm{C}$ and inserted into the IVOS computerized spermatozoal motion analyzer for evaluation. A total of 10 microscopic fields and a minimum of 500 spermatozoa were examined. Preset values for the IVOS system consisted of the 
following: frames acquired -45 ; frame rate $-60 \mathrm{~Hz}$; minimum contract -70 ; minimum cell size -4 pixels; minimum static contrast -30 ; straightness threshold for progressive motility - 50; average-path velocity (VAP) threshold for progressive motility - 30; VAP threshold for static cells - 15; cell intensity - 106; static head size -0.60 to 2.00 ; static head intensity -0.20 to 2.01 ; static elongation -40 to 85 ; LED illumination intensity 2200; Experimental endpoints included: 1) percentage of motile spermatozoa (MOT); percentage of progressively motile spermatozoa (PMOT); mean curvilinear velocity $(\mathrm{VCL} ; \mu \mathrm{m} / \mathrm{s})$; mean average-path velocity $(\mathrm{VAP} ; \mu \mathrm{m} / \mathrm{s})$; mean straight-line velocity $(\mathrm{VSL} ; \mu \mathrm{m} / \mathrm{s})$, and linearity ([VSL/VCL]x100; \%;LIN).

\section{Sperm Chromatin Structure Assay}

This assay was performed as previously described [29-31]. Individual semen samples were thawed in a water bath set at $35-37{ }^{\circ} \mathrm{C}$. A five- $\mu$ l aliquot of thawed semen was combined with $195 \mu$ l of a buffered solution which was then cobined with a low $\mathrm{pH}$ $(\sim 1.2)$ solution $(400 \mu \mathrm{l})$ for $30 \mathrm{~s}$. A solution of the heterochromatic dye, acridine orange, was added $(1.2 \mathrm{ml}$ at $4.0 \mu \mathrm{g} / \mathrm{ml})$ to the sample and it was processed immediately on a flow cytometer (FACScan; Becton Dickinson, Mountain View, CA, USA). The sample was allowed to pass through the tubing for $2 \mathrm{~min}$ before evaluation of cells. A cell flow rate of 200 cells/s was used and a total of 5000 events were evaluated per sample. The flow cytometer was adjusted so that the mean green fluorescence was set at 500 channels (FL-1@ @ 500) and mean red fluorescence at 150 channels (FL-3@ 150) 
fluorescence. Data were acquired in a list-mode and translated by WinList ${ }^{\mathrm{TM}}$ software (Verity Software House, Topsham, ME, USA) to PC-files, then analyzed using the same software. Quantification of DNA denaturation in each cell was determined by the term alpha-t, which is defined as the ratios of red/red + green fluorescence. The alpha-t designation is used to describe the relationship between the amounts of green (doublestranded DNA) and red (single-stranded DNA) fluorescence. The results were recorded as both scattergrams and frequency histographs. The endpoint, percent COMPat (COMP; the percentage of cells outside the main population) was determined by selecting those cells to the right of the main population, and represents the number of cells outside the main population, as a percentage of the total number of cells evaluated.

\section{Evaluation of Sperm Acrosomal and Plasma Membrane Integrity}

The integrity of spermatozoal acrosomal and plasma membranes was evaluated using a modification of procedures described previously [32-35].

Fifty $\mu 1$ of thawed semen were added to $133 \mu$ of Dulbecco's phosphate buffered saline (PBS; Invitrogen Gibco, ${ }^{\circledR}$ Carlsbad, CA, USA). Three $\mu$ l of propidium iodide (Invitrogen Molecular Probes, Euigene, OR, USA; $2.4 \mathrm{mM}$ working solution) and $10 \mu \mathrm{l}$ Pisum sativum agglutinin (PSA)-FITC conjugate (Sigma-Aldrich, St. Louis, MO, USA; $0.05 \mathrm{mg} / \mathrm{ml}$ working solution) were added to the semen-buffer solution. The samples were incubated at room temperature (approximately $25^{\circ} \mathrm{C}$ ) in the dark for 10 minutes. Fifty $\mu$ of semen were then mixed with $1 \mathrm{ml}$ PBS and processed immediately on a flow 
cytometer (FACScan; Becton Dickinson, Mountain View, CA, USA). The sample was allowed to pass through the tubing for $30 \mathrm{~s}$ before evaluation of cells. A cell flow rate of $300 \mathrm{cells} / \mathrm{s}$ was used and a total of 5000 events were evaluated per sample. The voltage settings on the flow cytometer were as follows: SSC 240, FL1 798, FL2 657, and FL3 150. The compensation was set at FL1 $1.9 \%$ of FL2, and FL2 $18.8 \%$ of FL1. Data were acquired using a log scale and anylazed by WinList ${ }^{\mathrm{TM}}$ software, with scatterplots divided into quadrants: minimal green and red fluorescence (representing spermatozoa with intact plasma membrane and intact acrosomal membrane; AIVIAB); minimal green and enhanced red fluorescence (representing spermatozoa with damaged plasma membrane and intact acrosomal membrane; minimal red and enhanced green fluorescence (representing spermatozoa with intact plasma membrane and damaged acrosomal membrane); and enhanced red and greed fluorescence (representing spermatozoa with damaged plasma membrane and damaged acrosomal membrane). Data were also sorted by spermatozoa with intact plasma membrane, regardless of acrosomal status (VIAB) and spermatozoa with intact acrosomal membrane, regardless of plasma membrane status (AI).

\section{Statistical Analysis}

The effects of extender (LE, MF), pre-freeze cooling rate (SLOW, FAST), and post-thaw diluent (INRA96, FM) on 10 experimental endpoints (MOT, PMOT, VCL, VAP, VSL, LIN, AIVIAB, AI, VIAB, and COMP) were evaluated using a general linear 
model [36]. Variables measured in percentages were transformed to angles corresponding to arc sine of the square root of percentage for variance analyses. The Student-Newman-Keuls multiple range test was used to separate main effect means when treatment $\mathrm{F}$ ratios were significant $(\mathrm{P}<0.05)$ and for mean separation where significant interactions occurred $(\mathrm{P}<0.05)$. The linear relationships among post-thaw dependent variables and among cooling and freezing effects on dependent variables were evaluated using a general correlations procedure [36]. 


\section{RESULTS}

The main effects of cryopreservation extender (LE vs MF), pre-freeze cooling rate (SLOW vs FAST) and post-thaw diluent (INRA96 vs FM) are presented in Table 1. Overall, eight of ten experimental endpoints (MOT, PMOT, VAP, VSL, LIN AIVIAB, AI, and VIAB) were affected by extender type, with LE extender yielding higher values than MF extender for all of these outcomes $(\mathrm{P}<0.05)$. Mean VCL and COMP were not impacted by extender type $(\mathrm{P}>0.05)$. Exposure of extended semen to a slow pre-freeze cooling period resulted in increased values for six of ten endpoints, as compared to a fast pre-freeze cooling period $(\mathrm{P}<0.05)$. Mean VAP, VSL, COMP were unaffected by prefreeze cooling rate $(\mathrm{P}>0.05)$. Mean LIN was slightly greater for semen exposed to a fast pre-freeze cooling period $(\mathrm{P}<0.05)$. Post-thaw diluent resulted in significant differences in seven of 10 endpoints, with INRA96 yielding higher mean values than FM for MOT, PMOT, VCL, VAP, and VSL $(\mathrm{P}<0.05)$. Treatment group FM yielded slightly higher values than INRA96 for LIN and VIAB $(\mathrm{P}<0.05)$. A treatment effect was not detected for AIVIAB, AI, and COMP $(\mathrm{P}>0.05)$.

Significant extender $\mathrm{x}$ rate interactions $(\mathrm{P}<0.05)$ were detected for the variables MOT, AIVIAB, AI and VIAB. Mean values for these endpoints were higher following spermatozoal exposure to a SLOW pre-freeze cooling period, regardless of freezing extender type $(\mathrm{P}<0.05)$. The effect of pre-freezing cooling rate on MOT, AIVIAB, AI, and VIAB appeared to be more pronounced in spermatozoa cryopreserved in MF 
extender, as compared to LE extender (Table 2). Within treatment groups SLOW and

FAST, mean MOT, AIVIAB, AI, and VIAB were higher $(\mathrm{P}<0.05)$ for spermatozoa

cryopreserved in LE extender, as opposed to MF extender (Table 3). The effect of

extender type appeared to be more pronounced when spermatozoa were subjected to a

FAST cooling rate.

Table 1: Main effects of extender, rate, and diluent on mean $( \pm \mathrm{SD})$ value of spermatozoal motility, viability, acrosomal intactness, and chromatin quality.

\begin{tabular}{|c|c|c|c|c|c|c|}
\hline $\begin{array}{l}\text { Laboratory } \\
\text { parameter }^{\S \mathrm{a}}\end{array}$ & Freezing e & xtender & Pre-freeze & cool rate & Post-thaw & diluent \\
\hline & $\mathrm{LE}^{\mathrm{b}}$ & $\mathrm{MF}^{\mathrm{c}}$ & SLOW $^{\mathrm{d}}$ & FAST $^{\mathrm{e}}$ & INRA $^{\text {f }}$ & $\mathrm{FM}^{\mathrm{g}}$ \\
\hline MOT & $46 \mathrm{a}(1.1)$ & $26 b(1.5)$ & $42 \mathrm{a}(1.5)$ & $30 b(1.6)$ & $40 \mathrm{a}(1.5)$ & $33 b(1.8)$ \\
\hline PMOT & $20 \mathrm{a}(1.0)$ & $7 b(0.8)$ & $17 \mathrm{a}(1.2)$ & $10 \mathrm{~b}(1.0)$ & $14 \mathrm{a}(1.1)$ & $13 b(1.2)$ \\
\hline VCL & $131 \mathrm{a}(2.4)$ & $131 \mathrm{a}(3.0)$ & $133 a(2.6)$ & $128 b(2.9)$ & $137 \mathrm{a}(2.6)$ & $125 \mathrm{~b}(2.7)$ \\
\hline VAP & $68 \mathrm{a}(1.2)$ & $64 b(1.5)$ & $67 \mathrm{a}(1.3)$ & $66 \mathrm{a}(1.4)$ & $69 \mathrm{a}(1.2)$ & $64 b(1.4)$ \\
\hline VSL & $57 \mathrm{a}(1.0)$ & $51 \mathrm{~b}(1.2)$ & $54 \mathrm{a}(1.1)$ & $54 \mathrm{a}(1.2)$ & $55 \mathrm{a}(1.0)$ & $52 b(1.3)$ \\
\hline LIN & $45 \mathrm{a}(0.6)$ & $41 \mathrm{~b}(0.5)$ & $42 \mathrm{~b}(0.5)$ & $44 a(0.7)$ & $42 \mathrm{~b}(0.4)$ & $44 a(0.7)$ \\
\hline AIVIAB & $44 \mathrm{a}(1.0)$ & $26 \mathrm{~b}(1.4)$ & $42 \mathrm{a}(1.1)$ & $27 \mathrm{~b}(1.5)$ & $34 \mathrm{a}(1.5)$ & $35 \mathrm{a}(1.6)$ \\
\hline AI & $75 \mathrm{a}(1.2)$ & $55 b(2.5)$ & $77 \mathrm{a}(0.9)$ & $52 \mathrm{~b}(2.4)$ & $65 \mathrm{a}(2.3)$ & $65 \mathrm{a}(2.2)$ \\
\hline VIAB & $46 \mathrm{a}(1.0)$ & $26 \mathrm{~b}(1.4)$ & $43 \mathrm{a}(1.1)$ & $28 b(1.6)$ & $35 b(1.6)$ & $37 \mathrm{a}(1.7)$ \\
\hline $\mathrm{COMP}_{\alpha \mathrm{t}}$ & $8 \mathrm{a}(0.3)$ & $7 \mathrm{a}(0.3)$ & $7 \mathrm{a}(0.3)$ & $8 \mathrm{a}(0.4)$ & $7 a(0.3)$ & $7 \mathrm{a}(0.3)$ \\
\hline
\end{tabular}

${ }^{\S}$ Percentage data (MOT, PMOT, LIN, AIVIAB, AI, VIAB, COMP ${ }_{\alpha t}$ ) were arc sine-root transformed for normalization prior to statistical analysis; untransformed data are presented for ease of interpretation. Within extender, rate, diluent, and within laboratory parameter, means with different letters $(\mathrm{a}$ and $\mathrm{b})$ differ $(\mathrm{P}<0.05)$.

${ }^{a}$ MOT: total spermatozoal motility (\%); PMOT: progressive spermatozoal motility (\%); VCL: curvilinear velocity $(\mu \mathrm{m} / \mathrm{s})$; VAP: average-path velocity $(\mu \mathrm{m} / \mathrm{s})$; VSL: straightline velocity $(\mu \mathrm{m} / \mathrm{s})$; LIN: linearity ([VSL/VCL]100; \%); AIVIAB: acrosome intact viable spermatozoa (\%); AI: acrosome intact spermatozoa (\%); VIAB: viable spermatozoa (\%); COMP ${ }_{\alpha t}$ : percentage of spermatozoa with at value outside the main population $(\%)$.

${ }^{\mathrm{b}} \mathrm{LE}=\mathrm{E}-\mathrm{Z}$ Freezin ${ }^{\mathrm{TM}}$ "LE" semen extender $(\mathrm{n}=84)$.

${ }^{c} \mathrm{MF}=\mathrm{E}-\mathrm{Z}$ Freezin ${ }^{\mathrm{TM}}$ "MFR5" semen extender $(\mathrm{n}=84)$.

${ }^{\mathrm{d}}$ SLOW $=$ Slow pre-freeze cooling rate $(\mathrm{n}=88)$.

${ }^{\mathrm{e}} \mathrm{FAST}=$ Fast pre-freeze cooling rate $(\mathrm{n}=80)$.

${ }^{\mathrm{f}}$ INRA = INRA 96 semen extender used as post-thaw diluent $(\mathrm{n}=84)$.

g FM = Freezing Media ("LE" or "MFR5" semen extender) used as post-thaw diluent $(n=84)$. 
Table 2: Effects of pre-freeze cooling rate on mean $( \pm \mathrm{SD})$ value of spermatozoal motility, viability, acrosomal intactness, and chromatin quality as sorted by extender type.

\begin{tabular}{|c|c|c|c|c|c|c|}
\hline \multirow[t]{2}{*}{$\begin{array}{l}\text { Laboratory } \\
\text { parameter }^{\S \underline{a}}\end{array}$} & \multirow{2}{*}{$\begin{array}{l}\text { Freezing } \\
\text { extender } \\
\text { LE }\end{array}$} & \multicolumn{2}{|c|}{$\underline{\text { Pre-freeze cool rate }}$} & \multirow{2}{*}{$\begin{array}{l}\text { Freezing } \\
\text { extender } \\
\mathrm{MF}\end{array}$} & \multicolumn{2}{|c|}{$\underline{\text { Pre-freeze cool rate }}$} \\
\hline & & $\mathrm{SLOW}^{\mathrm{b}}$ & $\mathrm{FAST}^{\mathrm{c}}$ & & $\mathrm{SLOW}^{\mathrm{d}}$ & $\mathrm{FAST}^{\mathrm{e}}$ \\
\hline MOT & LE & $51 \mathrm{a}(1.4)$ & $42 b(1.3)$ & $\mathrm{MF}$ & $33 a(2.0)$ & $18 b(1.5)$ \\
\hline PMOT & LE & $23 a(1.5)$ & $16 \mathrm{a}(1.2)$ & MF & $11 \mathrm{a}(1.3)$ & $4 a(0.6)$ \\
\hline VCL & LE & $134 \mathrm{a}(3.4)$ & $127 \mathrm{a}(3.4)$ & MF & $133 \mathrm{a}(3.8)$ & $129 \mathrm{a}(4.7)$ \\
\hline VAP & LE & $69 \mathrm{a}(1.6)$ & $67 \mathrm{a}(1.7)$ & MF & $64 \mathrm{a}(2.0)$ & $65 \mathrm{a}(2.3)$ \\
\hline VSL & LE & $57 \mathrm{a}(1.4)$ & $56 \mathrm{a}(1.5)$ & MF & $51 \mathrm{a}(1.6)$ & $51 \mathrm{a}(1.8)$ \\
\hline LIN & $\mathrm{LE}$ & $44 a(0.7)$ & $46 \mathrm{a}(0.8)$ & MF & $40 \mathrm{a}(0.6)$ & $42 \mathrm{a}(0.9)$ \\
\hline AIVIAB & $\mathrm{LE}$ & $48 \mathrm{a}(1.2)$ & $39 b(1.1)$ & MF & $35 \mathrm{a}(1.2)$ & $15 b(1.1)$ \\
\hline AI & LE & $78 \mathrm{a}(1.5)$ & $71 b(1.6)$ & MF & $75 \mathrm{a}(1.1)$ & $34 \mathrm{~b}(2.0)$ \\
\hline VIAB & LE & $51 \mathrm{a}(1.1)$ & $41 b(1.2)$ & MF & $36 a(1.2)$ & $16 b(1.1)$ \\
\hline $\mathrm{COMP}_{\alpha \mathrm{t}}$ & LE & $7 \mathrm{a}(0.4)$ & $8 \mathrm{a}(0.5)$ & $\mathrm{MF}$ & $7 \mathrm{a}(0.4)$ & $8 \mathrm{a}(0.6)$ \\
\hline
\end{tabular}

${ }^{\S}$ Percentage data (MOT, PMOT, LIN, AIVIAB, AI, VIAB, COMP ${ }_{\alpha t}$ ) were arc sine-root transformed for normalization prior to statistical analysis; untransformed data are presented for ease of interpretation. Within extender, rate, and within laboratory parameter, means with different letters $(\mathrm{a}$ and $\mathrm{b})$ differ $(\mathrm{P}<0.05)$.

${ }^{a}$ MOT: total spermatozoal motility (\%); PMOT: progressive spermatozoal motility (\%); VCL: curvilinear velocity $(\mu \mathrm{m} / \mathrm{s})$; VAP: average-path velocity $(\mu \mathrm{m} / \mathrm{s})$; VSL: straightline velocity $(\mu \mathrm{m} / \mathrm{s})$; LIN: linearity ([VSL/VCL]100; \%); AIVIAB: acrosome intact viable spermatozoa (\%); AI: acrosome intact spermatozoa (\%); VIAB: viable spermatozoa (\%); COMP ${ }_{\alpha t}$ : percentage of spermatozoa with at value outside the main population $(\%)$.

${ }^{\mathrm{b}}$ LE SLOW = semen frozen in E-Z Freezin ${ }^{\mathrm{TM}}$ "LE" semen extender using the static vapor method with a slow pre-freeze cooling rate applied $(n=44)$.

${ }^{\mathrm{c}} \mathrm{LE}$ FAST $=$ semen frozen in E-Z Freezin ${ }^{\mathrm{TM}}$ "LE" semen extender using the static vapor method with no pre-freeze cooling rate applied $(n=40)$.

${ }^{\mathrm{d}}$ MF SLOW = semen frozen in E-Z Freezin ${ }^{\mathrm{TM}}$ "MFR5" semen extender using the static vapor method with a slow pre-freeze cooling rate applied $(n=44)$.

"MF FAST = semen frozen in E-Z Freezin "MM "MFR5" semen extender using the static vapor method with no pre-freeze cooling rate applied $(n=40)$. 
Table 3: Effects of extender type on mean $( \pm \mathrm{SD})$ value of spermatozoal motility, viability, acrosomal intactness, and chromatin quality as sorted by pre-freeze cooling rate.

\begin{tabular}{|c|c|c|c|c|c|c|}
\hline \multirow[t]{2}{*}{$\begin{array}{l}\text { Laboratory } \\
\text { parameter }^{\S}\end{array}$} & \multirow{2}{*}{$\begin{array}{l}\text { Pre-freeze } \\
\text { cool rate } \\
\text { FAST }\end{array}$} & Freezing & extender & \multirow{2}{*}{$\begin{array}{l}\text { Pre-freeze } \\
\text { cool rate } \\
\text { SLOW }\end{array}$} & \multicolumn{2}{|c|}{ Freezing extender } \\
\hline & & $\mathrm{LE}^{\mathrm{b}}$ & $\mathrm{MF}^{\mathrm{c}}$ & & $\mathrm{LE}^{\mathrm{d}}$ & $\mathrm{MF}^{\mathrm{e}}$ \\
\hline MOT & FAST & $42 \mathrm{a}(1.3)$ & $18 b(1.5)$ & SLOW & $51 \mathrm{a}(1.4)$ & $33 b(2.0)$ \\
\hline PMOT & FAST & $16 \mathrm{a}(1.2)$ & $4 a(0.6)$ & SLOW & $23 \mathrm{a}(1.5)$ & $11 \mathrm{a}(1.3)$ \\
\hline VCL & FAST & $127 \mathrm{a}(3.4)$ & $129 a(4.7)$ & SLOW & $134 \mathrm{a}(3.4)$ & $133 \mathrm{a}(3.8)$ \\
\hline VAP & FAST & $67 \mathrm{a}(1.7)$ & $65 \mathrm{a}(2.3)$ & SLOW & $69 a(1.6)$ & $64 \mathrm{a}(2.0)$ \\
\hline VSL & FAST & $56 \mathrm{a}(1.5)$ & $51 \mathrm{a}(1.8)$ & SLOW & $57 \mathrm{a}(1.4)$ & $51 \mathrm{a}(1.6)$ \\
\hline LIN & FAST & $46 \mathrm{a}(0.8)$ & $42 \mathrm{a}(0.9)$ & SLOW & $44 a(0.7)$ & $40 \mathrm{a}(0.6)$ \\
\hline AIVIAB & FAST & 39a (1.1) & $15 b(1.1)$ & SLOW & $48 \mathrm{a}(1.2)$ & $35 b(1.2)$ \\
\hline AI & FAST & 71a (1.6) & $34 b(2.0)$ & SLOW & $78 \mathrm{a}(1.5)$ & $75 b(1.1)$ \\
\hline VIAB & FAST & $41 \mathrm{a}(1.2)$ & $16 b(1.1)$ & SLOW & $51 \mathrm{a}(1.1)$ & $36 \mathrm{~b}(1.2)$ \\
\hline $\mathrm{COMP}_{\alpha \mathrm{t}}$ & FAST & $8 \mathrm{a}(0.5)$ & $8 \mathrm{a}(0.6)$ & SLOW & $7 \mathrm{a}(0.4)$ & $7 a(0.4)$ \\
\hline
\end{tabular}

${ }^{\S}$ Percentage data (MOT, PMOT, LIN, AIVIAB, AI, VIAB, COMP $\alpha$ ) were arc sine-root transformed for normalization prior to statistical analysis; untransformed data are presented for ease of interpretation. Within extender, rate, and within laboratory parameter, means with different letters $(\mathrm{a}$ and $\mathrm{b})$ differ $(\mathrm{P}<0.05)$.

${ }^{a}$ MOT: total spermatozoal motility (\%); PMOT: progressive spermatozoal motility (\%); VCL: curvilinear velocity $(\mu \mathrm{m} / \mathrm{s})$; VAP: average-path velocity $(\mu \mathrm{m} / \mathrm{s})$; VSL: straightline velocity $(\mu \mathrm{m} / \mathrm{s})$; LIN: linearity ([VSL/VCL]100; \%); AIVIAB: acrosome intact viable spermatozoa (\%); AI: acrosome intact spermatozoa (\%); VIAB: viable spermatozoa (\%); COMP ${ }_{\alpha t}$ : percentage of spermatozoa with $\alpha$ t value outside the main population $(\%)$.

${ }^{b}$ LE FAST = semen frozen in E-Z Freezin ${ }^{\mathrm{TM}}$ "LE" semen extender using the static vapor method with no pre-freeze cooling rate applied $(n=40)$.

${ }^{c}$ MF FAST = semen frozen in E-Z Freezin "MM "MFR5" semen extender using the static vapor method with no pre-freeze cooling rate applied $(n=40)$.

${ }^{\mathrm{d}} \mathrm{LE}$ SLOW $=$ semen frozen in E-Z Freezin ${ }^{\mathrm{TM}}$ "LE" semen extender using the static vapor method with a slow pre-freeze cooling rate applied $(n=44)$.

"MF SLOW = semen frozen in E-Z Freezin "M "MFR5" semen extender using the static vapor method with a slow pre-freeze cooling rate applied $(n=44)$.

Significant extender $\mathrm{x}$ diluent interactions $(\mathrm{P}<0.05)$ were detected for MOT, PMOT, VCL, VAP, VSL, and LIN. Within Group MF, mean MOT, PMOT, VCL, 
VAP, and VSL were higher in INRA96 diluent, as compared to FM diluent $(\mathrm{P}<0.05)$.

Within Group LE, FM diluent yielded slightly higher values than INRA96 diluent for PMOT, VAP, VSL, and LIN (P<0.05; Table 4).

Table 4: Effects of post-thaw diluent on mean $( \pm \mathrm{SD})$ value of spermatozoal motility, viability, acrosomal intactness, and chromatin quality as sorted by extender type.

\begin{tabular}{|c|c|c|c|c|c|c|}
\hline \multirow[t]{2}{*}{$\begin{array}{l}\text { Laboratory } \\
\text { parameter }^{\S}\end{array}$} & \multirow{2}{*}{$\begin{array}{l}\text { Freezing } \\
\text { extender } \\
\text { LE }\end{array}$} & \multicolumn{2}{|c|}{$\underline{\text { Post-thaw diluent }}$} & \multirow{2}{*}{$\begin{array}{l}\text { Freezing } \\
\text { extender } \\
\mathrm{MF}\end{array}$} & \multicolumn{2}{|c|}{ Post-thaw diluent } \\
\hline & & INRA $^{b}$ & $\mathrm{FM}^{\mathrm{c}}$ & & INRA $^{\mathrm{d}}$ & $\mathrm{FM}^{\mathrm{e}}$ \\
\hline MOT & $\mathrm{LE}$ & $47 \mathrm{a}(1.4)$ & $46 a(1.6)$ & MF & $33 \mathrm{a}(2.2)$ & $20 \mathrm{~b}(1.4)$ \\
\hline PMOT & LE & $18 \mathrm{~b}(1.4)$ & $21 \mathrm{a}(1.4)$ & MF & $11 \mathrm{a}(1.4)$ & $4 b(0.5)$ \\
\hline VCL & LE & $132 \mathrm{a}(3.3)$ & $130 \mathrm{a}(3.6)$ & $\mathrm{MF}$ & $143 \mathrm{a}(3.8)$ & $120 \mathrm{~b}(4.0)$ \\
\hline VAP & LE & $67 b(1.6)$ & $70 \mathrm{a}(1.7)$ & $\mathrm{MF}$ & 71a (1.8) & $58 b(1.9)$ \\
\hline VSL & LE & $55 \mathrm{~b}(1.4)$ & $59 a(1.4)$ & $\mathrm{MF}$ & $56 a(1.5)$ & $46 b(1.6)$ \\
\hline LIN & LE & $43 b(0.6)$ & $47 \mathrm{a}(0.8)$ & $\mathrm{MF}$ & $41 \mathrm{a}(0.5)$ & $40 \mathrm{a}(0.9)$ \\
\hline AIVIAB & LE & $43 \mathrm{a}(1.4)$ & $44 a(1.5)$ & $\mathrm{MF}$ & $26 a(1.9)$ & $26 a(1.9)$ \\
\hline AI & LE & $75 \mathrm{a}(1.6)$ & $75 \mathrm{a}(1.7)$ & MF & $55 \mathrm{a}(3.6)$ & $56 a(3.6)$ \\
\hline VIAB & LE & $44 \mathrm{a}(1.4)$ & $48 \mathrm{a}(1.3)$ & MF & $26 a(1.9)$ & $27 \mathrm{a}(1.9)$ \\
\hline $\mathrm{COMP}_{\alpha \mathrm{t}}$ & LE & $8 \mathrm{a}(0.5)$ & $8 \mathrm{a}(0.5)$ & MF & $7 \mathrm{a}(0.5)$ & $7 \mathrm{a}(0.5)$ \\
\hline
\end{tabular}

${ }^{\S}$ Percentage data (MOT, PMOT, LIN, AIVIAB, AI, VIAB, COMP ${ }_{\alpha t}$ ) were arc sine-root transformed for normalization prior to statistical analysis; untransformed data are presented for ease of interpretation. Within extender, diluent, and within laboratory parameter, means with different letters $(\mathrm{a}$ and $\mathrm{b})$ differ $(\mathrm{P}<0.05)$.

${ }^{a}$ MOT: total spermatozoal motility (\%); PMOT: progressive spermatozoal motility (\%); VCL: curvilinear velocity $(\mu \mathrm{m} / \mathrm{s})$; VAP: average-path velocity $(\mu \mathrm{m} / \mathrm{s})$; VSL: straightline velocity $(\mu \mathrm{m} / \mathrm{s})$; LIN: linearity ([VSL/VCL]100; \%); AIVIAB: acrosome intact viable spermatozoa (\%); AI: acrosome intact spermatozoa (\%); VIAB: viable spermatozoa (\%); COMP ${ }_{\alpha t}$ : percentage of spermatozoa with at value outside the main population $(\%)$.

${ }^{b}$ LE INRA = semen frozen in E-Z Freezin ${ }^{T M}$ "LE" semen extender and diluted in INRA 96 semen extender for post-thaw analysis $(n=42)$.

${ }^{c} \mathrm{LE} F M=$ semen frozen in E-Z Freezin ${ }^{\mathrm{TM}}$ "LE" semen extender and diluted in E-Z Freezin ${ }^{\text {TM }}$ "LE" semen extender for post-thaw analysis $(n=42)$.

${ }^{\mathrm{d}}$ MF INRA = semen frozen in E-Z Freezin "MM "MFR5" semen extender and diluted in INRA 96 semen extender for post-thaw analysis $(n=42)$.

${ }^{\mathrm{e}} \mathrm{MF}$ FM = semen frozen in E-Z Freezin "TM "MFR5" semen extender and diluted in E-Z Freezin "MM "MFR5" semen extender for post-thaw analysis $(n=42)$. 
Significant rate $\mathrm{x}$ diluent interactions $(\mathrm{P}<0.05)$ were detected for MOT, PMOT, and LIN.(P<0.05), as revealed in Table 5. Within Group SLOW, mean values for MOT and PMOT were higher for INRA96 than for FM $(\mathrm{P}<0.05)$. Within Group FAST, mean MOT was higher in INRA96 than FM $(\mathrm{P}<0.05)$, whereas mean LIN was slightly higher in FM than in INRA96 $(\mathrm{P}<0.05)$.

For post-thaw data, mean CASMA values for MOT and PMOT were highly correlated $(\mathrm{P}<0.05)$ to $\mathrm{FC}$ values for AIVIAB, AI, and VIAB (Table 6). The correlations among dependent variables were generally more pronounced when the dataset included all treatments $(\mathrm{N}=168)$. When data were sorted to provide the optimal semen treatment (ie, LE extender, SLOW cooling rate, and INRA96 diluent; $\mathrm{N}=22$ ), the number of significant correlations between variables was reduced. This was attributed, to a large part, to the smaller sample size and reduced variability for individual endpoints (Table 7).

The linear relationships of T0 to T24 (ie, immediate to cool-stored) spermatozoal measures were as follows: MOT $(r=0.86, \mathrm{P}<0.0001)$, PMOT $(r=0.88, \mathrm{P}<0.0001)$, $\operatorname{VCL}(r=0.79, \mathrm{P}<0.0001), \operatorname{VAP}(r=0.74, \mathrm{P}<0.0001), \operatorname{VSL}(r=0.82, \mathrm{P}<0.0001), \operatorname{LIN}(r$ $=0.87, \mathrm{P}<0.0001)$, and COMP $(r=0.71, \mathrm{P}<0.0001)$. The T0 MOT was also highly correlated with T0 PMOT and T24 PMOT $(r=0.80 ; \mathrm{P}<0.0001$ and $r=0.75, \mathrm{P}<0.0001$, respectively). The T0 COMP was not correlated with other $\mathrm{T} 0$ values $(\mathrm{P}>0.05)$, but was negatively correlated with T24 PMOT $(r=-0.44 ; \mathrm{P}=0.03)$. 
Table 5: Effects of post-thaw diluent on mean $( \pm \mathrm{SD})$ value of spermatozoal motility, viability, acrosomal intactness, and chromatin quality as sorted by pre-freeze cooling rate.

\begin{tabular}{|c|c|c|c|c|c|c|}
\hline \multirow[t]{2}{*}{$\begin{array}{l}\text { Laboratory } \\
\text { parameter }^{\$ \text { a }}\end{array}$} & \multirow{2}{*}{$\begin{array}{l}\text { Pre-freeze } \\
\text { cool rate } \\
\text { FAST }\end{array}$} & \multicolumn{2}{|c|}{ Post-thaw diluent } & \multirow{2}{*}{$\begin{array}{l}\text { Pre-freeze } \\
\text { cool rate } \\
\text { SLOW }\end{array}$} & \multicolumn{2}{|c|}{$\underline{\text { Post-thaw diluent }}$} \\
\hline & & $\mathrm{INRA}^{\mathrm{b}}$ & $\mathrm{FM}^{\mathrm{c}}$ & & INRA $^{\mathrm{d}}$ & $\mathrm{FM}^{\mathrm{e}}$ \\
\hline MOT & FAST & $32 \mathrm{a}(2.3)$ & $28 b(2.3)$ & SLOW & $47 \mathrm{a}(1.4)$ & $37 b(2.6)$ \\
\hline PMOT & FAST & $10 \mathrm{a}(1.3)$ & $10 \mathrm{a}(1.5)$ & SLOW & $19 \mathrm{a}(1.4)$ & $15 b(1.9)$ \\
\hline VCL & FAST & $135 \mathrm{a}(3.7)$ & $122 \mathrm{a}(4.2)$ & SLOW & $139 \mathrm{a}(3.5)$ & $127 \mathrm{a}(3.5)$ \\
\hline VAP & FAST & $68 \mathrm{a}(1.7)$ & $64 \mathrm{a}(2.2)$ & SLOW & $70 \mathrm{a}(1.8)$ & $64 \mathrm{a}(1.8)$ \\
\hline VSL & FAST & $54 \mathrm{a}(1.4)$ & $53 a(2.0)$ & SLOW & $56 a(1.5)$ & $52 \mathrm{a}(1.7)$ \\
\hline LIN & FAST & $42 b(0.7)$ & $45 \mathrm{a}(1.1)$ & SLOW & $42 \mathrm{a}(0.5)$ & $42 \mathrm{a}(0.9)$ \\
\hline AIVIAB & FAST & $27 \mathrm{a}(2.2)$ & $27 \mathrm{a}(2.1)$ & SLOW & 41a (1.5) & $42 \mathrm{a}(1.6)$ \\
\hline AI & FAST & $52 \mathrm{a}(3.6)$ & $53 \mathrm{a}(3.4)$ & SLOW & $77 \mathrm{a}(1.3)$ & $77 \mathrm{a}(1.4)$ \\
\hline VIAB & FAST & $27 \mathrm{a}(2.2)$ & $30 \mathrm{a}(2.4)$ & SLOW & $42 \mathrm{a}(1.5)$ & $44 a(1.7)$ \\
\hline $\mathrm{COMP}_{\alpha \mathrm{t}}$ & FAST & $8 \mathrm{a}(0.5)$ & $8 \mathrm{a}(0.5)$ & SLOW & $7 \mathrm{a}(0.4)$ & $7 \mathrm{a}(0.4)$ \\
\hline
\end{tabular}

${ }^{\S}$ Percentage data (MOT, PMOT, LIN, AIVIAB, AI, VIAB, COMP $\alpha$ ) were arc sine-root transformed for normalization prior to statistical analysis; untransformed data are presented for ease of interpretation. Within rate, diluent, and within laboratory parameter, means with different letters $(\mathrm{a}$ and $\mathrm{b})$ differ $(\mathrm{P}<0.05)$.

${ }^{a}$ MOT: total spermatozoal motility (\%); PMOT: progressive spermatozoal motility (\%); VCL: curvilinear velocity $(\mu \mathrm{m} / \mathrm{s})$; VAP: average-path velocity $(\mu \mathrm{m} / \mathrm{s})$; VSL: straightline velocity $(\mu \mathrm{m} / \mathrm{s})$; LIN: linearity ([VSL/VCL]100; \%); AIVIAB: acrosome intact viable spermatozoa (\%); AI: acrosome intact spermatozoa (\%); VIAB: viable spermatozoa (\%); $\mathrm{COMP}_{\alpha t}$ : percentage of spermatozoa with $\alpha$ t value outside the main population $(\%)$.

${ }^{b}$ FAST INRA = semen frozen using static vapor method with no pre-freeze cooling rate applied and diluted in INRA 96 semen extender for post-thaw analysis $(n=40)$.

${ }^{\mathrm{c}}$ FAST FM = semen frozen using static vapor method with no pre-freeze cooling rate applied and diluted with the same freezing media ("LE" or "MFR5" semen extender) for post-thaw analysis $(\mathrm{n}=40)$.

${ }^{\mathrm{d}}$ SLOW INRA = semen frozen using static vapor method with a slow pre-freeze cooling rate applied and diluted in INRA 96 semen extender for post-thaw analysis $(n=44)$.

${ }^{\mathrm{e}}$ SLOW FM = semen frozen using static vapor method with a slow pre-freeze cooling rate applied and diluted with the same freezing media ("LE" or "MFR5" semen extender) for post-thaw analysis $(n=44)$. 
Table 6

Correlation coefficients and p-values among 10

dependent variables over all treatments (all data;

$\mathrm{N}=168$ ) and for semen exposed to LE extender, using a slow pre-freeze cooling rate, and using INRA 96 as

a post-thaw diluent $(\mathrm{N}=22)$.

\begin{tabular}{|c|c|c|c|c|c|c|c|c|c|c|c|}
\hline & MOT & РMOT & VCL & VAP & VSL & LIN & AIVIAB & $\mathrm{Al}$ & VIAB & COMP & \\
\hline MOT & & $\begin{array}{c}0.90 \\
0.0001\end{array}$ & $\begin{array}{c}0.27 \\
0.0004\end{array}$ & $\begin{array}{c}0.39 \\
0.0001\end{array}$ & $\begin{array}{c}0.48 \\
0.0001\end{array}$ & $\begin{array}{c}0.28 \\
0.0002\end{array}$ & $\begin{array}{c}0.78 \\
0.0001\end{array}$ & $\begin{array}{c}0.69 \\
0.0001\end{array}$ & $\begin{array}{c}0.79 \\
0.0001\end{array}$ & $\begin{array}{c}-0.18 \\
0.02\end{array}$ & MOT \\
\hline РMOT & $\begin{array}{c}0.94 \\
0.0001\end{array}$ & & $\begin{array}{c}0.31 \\
0.0001\end{array}$ & $\begin{array}{c}0.47 \\
0.0001\end{array}$ & $\begin{array}{c}0.56 \\
0.0001\end{array}$ & $\begin{array}{c}0.36 \\
0.0001\end{array}$ & $\begin{array}{c}0.69 \\
0.0001\end{array}$ & $\begin{array}{c}0.59 \\
0.0001\end{array}$ & $\begin{array}{c}0.69 \\
0.0001\end{array}$ & $\begin{array}{l}-0.18 \\
0.02\end{array}$ & РMOT \\
\hline $\mathrm{VCL}$ & NS & NS & & $\begin{array}{c}0.93 \\
0.0001\end{array}$ & $\begin{array}{c}0.83 \\
0.0001\end{array}$ & $\begin{array}{c}-0.32 \\
0.0001\end{array}$ & NS & NS & NS & NS & $\mathrm{VCL}$ \\
\hline VAP & NS & NS & $\begin{array}{c}0.96 \\
0.0001\end{array}$ & & $\begin{array}{c}0.96 \\
0.0001\end{array}$ & NS & NS & NS & NS & $\begin{array}{c}-0.18 \\
0.02\end{array}$ & VAP \\
\hline VSL & NS & NS & $\begin{array}{c}0.87 \\
0.0001\end{array}$ & $\begin{array}{c}0.97 \\
0.0001\end{array}$ & & $\begin{array}{c}0.22 \\
0.003\end{array}$ & $\begin{array}{c}0.25 \\
0.001\end{array}$ & $\begin{array}{c}0.23 \\
0.003\end{array}$ & $\begin{array}{c}0.24 \\
0.002\end{array}$ & $\begin{array}{l}-0.21 \\
0.005\end{array}$ & VSL \\
\hline LIN & $\begin{array}{l}0.51 \\
0.01\end{array}$ & $\begin{array}{l}0.54 \\
0.01\end{array}$ & NS & NS & NS & & $\begin{array}{l}0.19 \\
0.01\end{array}$ & NS & $\begin{array}{c}0.20 \\
0.008\end{array}$ & $\begin{array}{l}0.19 \\
0.01\end{array}$ & LIN \\
\hline AIVIAB & $\begin{array}{c}0.66 \\
0.0008\end{array}$ & $\begin{array}{c}0.56 \\
0.007\end{array}$ & NS & NS & NS & NS & & $\begin{array}{c}0.81 \\
0.0001\end{array}$ & $\begin{array}{c}0.98 \\
0.0001\end{array}$ & NS & AIVIAB \\
\hline Al & $\begin{array}{l}0.50 \\
0.02\end{array}$ & $\begin{array}{c}0.59 \\
0.004\end{array}$ & NS & NS & NS & NS & $\begin{array}{l}0.44 \\
0.04\end{array}$ & & $\begin{array}{c}0.79 \\
0.0001\end{array}$ & NS & $\mathrm{Al}$ \\
\hline VIAB & $\begin{array}{c}0.66 \\
0.0008\end{array}$ & $\begin{array}{c}0.55 \\
0.009\end{array}$ & NS & NS & NS & NS & $\begin{array}{c}0.99 \\
0.0001\end{array}$ & NS & & NS & VIAB \\
\hline \multirow[t]{2}{*}{ COMP } & $\begin{array}{c}-0.46 \\
0.03\end{array}$ & $\begin{array}{l}-0.49 \\
0.02\end{array}$ & NS & NS & NS & $\begin{array}{l}-0.46 \\
0.03\end{array}$ & NS & NS & NS & & COMP \\
\hline & МOT & PMOT & $\mathrm{VCL}$ & VAP & VSL & LIN & AIVIAB & $\mathrm{Al}$ & VIAB & COMP & \\
\hline
\end{tabular}

${ }^{\S} \mathrm{LE}=\mathrm{E}-\mathrm{Z}$ Freezin ${ }^{\mathrm{TM}}$ “LE” semen extender

INRA $96=$ INRA 96 semen extender 
Table 7

Comparison of values (Mean, S.D., Minimum, Maximum) for dependent variables for the complete post-thaw dataset which included all treatments $(\mathrm{N}=188)$ and the post-thaw dataset selected to optimize post-thaw spermatozoal quality (LE/ SLOW/ INRA post-thaw dataset; $\mathrm{N}=22$ ).

\begin{tabular}{|c|c|c|c|c|c|c|c|c|}
\hline & \multicolumn{4}{|c|}{\begin{tabular}{|l} 
Complete post-thaw dataset \\
$(\mathrm{N}=168)$
\end{tabular}} & \multicolumn{4}{|c|}{$\begin{array}{l}\text { LE / SLOW / INRA post-thaw } \\
\text { dataset }(\mathrm{N}=22)\end{array}$} \\
\hline & Mean & S.D. & Minimum & Maximum & Mean & S.D. & Minimum & Maximum \\
\hline$\overline{M O T}$ & 36 & 16 & 4 & 72 & 50 & 9 & 30 & 71 \\
\hline PMOT & 14 & 11 & 0 & 49 & 21 & 10 & 6 & 49 \\
\hline$\overline{\mathrm{VCL}}$ & 131 & 25 & 71 & 190 & 135 & 21 & 98 & 181 \\
\hline VAP & 66 & 12 & 39 & 96 & 67 & 11 & 48 & 91 \\
\hline$\overline{V S L}$ & 54 & 11 & 30 & 78 & 56 & 10 & 40 & 77 \\
\hline LIN & 43 & 5 & 31 & 62 & 42 & 4 & 36 & 49 \\
\hline AIVIAB & 35 & 14 & 4 & 67 & 48 & 7 & 26 & 57 \\
\hline$\overline{A I}$ & 65 & 21 & 13 & 94 & 79 & 9 & 59 & 94 \\
\hline VIAB & 36 & 15 & 4 & 68 & 49 & 7 & 27 & 58 \\
\hline COMP & 7 & 3 & 3 & 16 & 7 & 3 & 3 & 114 \\
\hline
\end{tabular}

${ }^{\S} \mathrm{LE} / \mathrm{SLOW} / \mathrm{INRA}=$ treatment group where semen was frozen using E-Z Freezin ${ }^{\mathrm{TM}}$ "LE" semen extender, applied a slow pre-freeze cooling rate, and diluted in INRA 96 for post-thaw analysis.

${ }^{\S}$ MOT: total spermatozoal motility (\%); PMOT: progressive spermatozoal motility (\%); VCL: curvilinear velocity $(\mu \mathrm{m} / \mathrm{s})$; VAP: average-path velocity $(\mu \mathrm{m} / \mathrm{s})$; VSL: straight-line velocity $(\mu \mathrm{m} / \mathrm{s})$; LIN: linearity ([VSL/VCL]100; \%); AIVIAB: acrosome intact viable spermatozoa (\%); AI: acrosome intact spermatozoa (\%); VIAB: viable spermatozoa $(\%)$; $\mathrm{COMP}_{\alpha \mathrm{t}}$ : percentage of spermatozoa with $\alpha$ t value outside the main population (\%).

Over all data, initial (T0) CASMA values, cool-stored (T24) CASMA values, and percent change in CASMA values following cooled storage (DIFF) did not provide 
useful predictive information regarding tolerance of spermatozoa to cryopreservation, as determined by all post-thaw CASMA and FC endpoints measured (Table 8). The majority of correlations between pre-freeze and post-thaw values were not significant ( $\mathrm{P}>0.05)$, and 26 of 47 significant $(\mathrm{P}<0.05)$ correlations were of lower magnitude (correlation coefficient less than 30). Data separation to provide optimal post-thaw semen quality (ie, LE extender / SLOW cooling rate / INRA diluent) yielded 42 significant correlations $(\mathrm{P}<0.05)$ between pre-freeze and post-thaw endpoints, and all significant correlations were moderate to high (ie, correlation coefficients ranging from 0.42 to 0.81 ; Table 9). In this data subset, the actual pre-freeze values for MOT, PMOT, VCL or COMP, either initially or following cooled storage of extended semen, provided better predictive information regarding post-thaw measures than did the percent change in these variables following cooled storage of extended semen. (Table 9).

Tables 10-21 represent correlation coefficients and p-values for fresh (T0, T24, DIFF) semen values and post-thaw endpoints for the individual treatment groups. The four fresh semen values used to show predictability on post-thaw endpoints were MOT, PMOT, VCL, and COMP. Overall, when evaluating the eight treatment groups there were only a few highly significant correlations (ie, correlation coefficients ranging from $\sim 0.60$ to $\sim 0.80$ ). For $\mathrm{T} 0$ fresh semen values, MOT and COMP showed the highest predictive value on post-thaw AI and COMP for the majority of treatment groups (Table 10 and Table 13). As for the T24 fresh semen values, MOT had a highly significant 
correlation with post-thaw AI (Table 14). There was also a high predictability of T24

PMOT on post-thaw LIN and AI (Table 15). The final significant correlation that

offered appreciable predictive value across the majority of treatment groups was seen

between T24 VCL and post-thaw VCL (Table 16).

Table 8

Correlation coefficients and p-values to determine effect of pre-freeze motility and chromatin values (T0, T24, DIFF) on post-thaw measures of semen quality following spermatozoal exposure to LE or MF extender, a SLOW or FAST pre-freeze cooling rate, and INRA 96 or FM diluent $(\mathrm{N}=168)$.

\begin{tabular}{|c|c|c|c|c|c|c|c|c|c|c|c|c|}
\hline & $\begin{array}{l}\text { TO } \\
\text { MOT }\end{array}$ & $\begin{array}{l}\text { TO } \\
\text { РMOT }\end{array}$ & $\begin{array}{l}\text { TO } \\
\text { VCL }\end{array}$ & $\begin{array}{l}\text { TO } \\
\text { COMP }\end{array}$ & $\begin{array}{l}\text { T24 } \\
\text { MOT }\end{array}$ & $\begin{array}{l}\text { T24 } \\
\text { РMOT }\end{array}$ & $\begin{array}{l}\text { T24 } \\
\text { VCL }\end{array}$ & $\begin{array}{l}\text { T24 } \\
\text { COMP }\end{array}$ & $\begin{array}{l}\text { DIFF } \\
\text { MOT }\end{array}$ & $\begin{array}{l}\text { DIFF } \\
\text { PMOT }\end{array}$ & $\begin{array}{l}\text { DIFF } \\
\text { VCL }\end{array}$ & $\begin{array}{l}\text { DIFF } \\
\text { COMP }\end{array}$ \\
\hline МОТ & NS & NS & NS & NS & NS & NS & NS & NS & NS & NS & NS & NS \\
\hline РМOT & NS & NS & NS & NS & NS & NS & NS & NS & NS & NS & $\begin{array}{c}-0.19 \\
0.01\end{array}$ & NS \\
\hline VCL & $\begin{array}{l}-0.17 \\
0.03\end{array}$ & $\begin{array}{c}-0.31 \\
0.0001\end{array}$ & $\begin{array}{c}0.29 \\
0.0001\end{array}$ & NS & $\begin{array}{l}-0.17 \\
0.03\end{array}$ & $\begin{array}{c}-0.33 \\
0.0001\end{array}$ & $\begin{array}{c}0.56 \\
0.0001\end{array}$ & $\begin{array}{l}-0.20 \\
0.008\end{array}$ & NS & NS & $\begin{array}{c}-0.39 \\
0.0001\end{array}$ & NS \\
\hline VAP & NS & $\begin{array}{l}-0.20 \\
0.009\end{array}$ & NS & $\begin{array}{l}-0.18 \\
0.02\end{array}$ & NS & $\begin{array}{l}-0.19 \\
\text { NS }\end{array}$ & $\begin{array}{c}0.42 \\
0.0001\end{array}$ & $\begin{array}{c}-0.32 \\
0.0001\end{array}$ & NS & NS & $\begin{array}{c}-0.39 \\
0.0001\end{array}$ & NS \\
\hline VSL & NS & NS & NS & $\begin{array}{c}-0.18 \\
0.02\end{array}$ & NS & NS & $\begin{array}{c}0.30 \\
0.0001\end{array}$ & $\begin{array}{c}-0.37 \\
0.0001\end{array}$ & NS & $\begin{array}{c}-0.18 \\
0.02\end{array}$ & $\begin{array}{c}-0.38 \\
0.0001\end{array}$ & NS \\
\hline LIN & $\begin{array}{l}0.16 \\
0.04\end{array}$ & $\begin{array}{c}0.38 \\
0.0001\end{array}$ & $\begin{array}{c}-0.40 \\
0.0001\end{array}$ & $\begin{array}{c}-0.31 \\
0.0001\end{array}$ & $\begin{array}{c}0.25 \\
0.0009\end{array}$ & $\begin{array}{c}0.47 \\
0.0001\end{array}$ & $\begin{array}{c}-0.37 \\
0.0001\end{array}$ & $\begin{array}{c}-0.30 \\
0.0001\end{array}$ & NS & NS & NS & NS \\
\hline AIVIAB & NS & NS & $\begin{array}{c}-0.18 \\
0.01\end{array}$ & NS & NS & NS & NS & $\begin{array}{c}-0.15 \\
0.04\end{array}$ & NS & $\begin{array}{c}-0.19 \\
0.01\end{array}$ & NS & NS \\
\hline Al & $\begin{array}{l}0.19 \\
0.02\end{array}$ & NS & NS & NS & $\begin{array}{c}0.22 \\
0.005\end{array}$ & $\begin{array}{c}0.23 \\
0.003\end{array}$ & NS & $\begin{array}{c}-0.18 \\
0.02\end{array}$ & NS & $\begin{array}{c}-0.17 \\
0.03\end{array}$ & NS & NS \\
\hline VIAB & NS & NS & NS & NS & NS & NS & NS & NS & NS & $\begin{array}{c}-0.16 \\
0.04\end{array}$ & NS & NS \\
\hline COMP & $\begin{array}{c}-0.40 \\
0.0001\end{array}$ & $\begin{array}{c}-0.47 \\
0.0001\end{array}$ & NS & $\begin{array}{c}0.57 \\
0.0001\end{array}$ & $\begin{array}{c}-0.29 \\
0.0002\end{array}$ & $\begin{array}{c}-0.48 \\
0.0001\end{array}$ & NS & $\begin{array}{c}0.48 \\
0.0001\end{array}$ & $\begin{array}{l}-0.19 \\
0.01\end{array}$ & NS & $\begin{array}{c}0.24 \\
0.005\end{array}$ & NS \\
\hline
\end{tabular}

${ }^{\S} \mathrm{LE}=\mathrm{E}-\mathrm{Z}$ Freezin ${ }^{\mathrm{TM}}$ “LE” semen extender.

$\mathrm{MF}=\mathrm{E}-\mathrm{Z}$ Freezin ${ }^{\mathrm{TM}}$ "MFR5" semen extender.

INRA $96=$ INRA 96 semen extender.

FM = Freezing Media ("LE" or "MFR5" semen extender) used as diluent.

${ }^{\mathrm{a}} \mathrm{T} 0=$ Fresh semen evaluated prior to cooling.

${ }^{\mathrm{b}} \mathrm{T} 24=$ Semen stored in an Equitainer ${ }^{\circledR}$ for 24 hours.

${ }^{c}$ DIFF $=$ Difference between $\mathrm{T} 0$ and T24. 
Table 9

Correlation coefficients and p-values to determine effect of pre-freeze motility and chromatin values (T0, T24, and DIFF) on post-thaw measures of semen quality following spermatozoal exposure to LE extender, a SLOW pre-freeze cooling rate, and INRA 96 diluent $(\mathrm{N}=22)$.

\begin{tabular}{|c|c|c|c|c|c|c|c|c|c|c|c|c|}
\hline & $\begin{array}{l}\text { TO }^{\mathrm{a}} \\
\text { MOT }\end{array}$ & $\begin{array}{l}\text { TO }^{\mathrm{a}} \\
\text { PMOT }\end{array}$ & $\begin{array}{l}\mathrm{TO}^{\mathrm{a}} \\
\mathrm{VCL}\end{array}$ & $\begin{array}{l}\mathrm{TO}^{\mathrm{a}} \\
\text { COMP }\end{array}$ & $\begin{array}{l}\text { T24 } \\
\text { MOT }\end{array}$ & $\begin{array}{l}\text { T24 } \\
\text { РMOT }\end{array}$ & $\begin{array}{l}T^{2} 4^{b} \\
V C L\end{array}$ & $\begin{array}{l}\mathrm{T} 24^{\mathrm{b}} \\
\text { COMP }\end{array}$ & $\begin{array}{l}\text { DIFF }^{c} \\
\text { MOT }\end{array}$ & $\begin{array}{l}\text { DIFF' } \\
\text { PMOT }\end{array}$ & $\begin{array}{l}\text { DIFF }^{\mathrm{c}} \\
\text { VCL }\end{array}$ & $\begin{array}{l}\text { DIFF }^{\mathrm{C}} \\
\text { COMP }\end{array}$ \\
\hline MOT & $\begin{array}{l}0.49 \\
0.02\end{array}$ & $\begin{array}{l}0.45 \\
0.03\end{array}$ & NS & $\begin{array}{c}-0.47 \\
0.03\end{array}$ & $\begin{array}{l}0.54 \\
0.01\end{array}$ & $\begin{array}{l}0.53 \\
0.01\end{array}$ & NS & $\begin{array}{c}-0.43 \\
0.04\end{array}$ & NS & NS & NS & NS \\
\hline РМOT & $\begin{array}{l}0.51 \\
0.01\end{array}$ & $\begin{array}{l}0.44 \\
0.04\end{array}$ & NS & $\begin{array}{c}-0.42 \\
0.04\end{array}$ & $\begin{array}{c}0.58 \\
0.005\end{array}$ & $\begin{array}{c}0.56 \\
0.007\end{array}$ & NS & $\begin{array}{r}-0.47 \\
0.03\end{array}$ & NS & NS & NS & NS \\
\hline VCL & NS & NS & $\begin{array}{l}0.43 \\
0.04\end{array}$ & NS & NS & $\begin{array}{c}-0.43 \\
0.04\end{array}$ & $\begin{array}{c}0.73 \\
0.0001\end{array}$ & NS & NS & NS & $\begin{array}{c}-0.43 \\
0.04\end{array}$ & NS \\
\hline VAP & NS & NS & NS & NS & NS & NS & $\begin{array}{c}0.65 \\
0.001\end{array}$ & $\begin{array}{c}-0.46 \\
0.03\end{array}$ & NS & NS & $\begin{array}{c}-0.44 \\
0.04\end{array}$ & NS \\
\hline VSL & NS & NS & NS & NS & NS & NS & $\begin{array}{c}0.54 \\
0.009\end{array}$ & $\begin{array}{l}-0.54 \\
0.009\end{array}$ & NS & NS & $\begin{array}{c}-0.45 \\
0.03\end{array}$ & NS \\
\hline LIN & NS & $\begin{array}{l}0.48 \\
0.02\end{array}$ & $\begin{array}{c}-0.43 \\
0.04\end{array}$ & $\begin{array}{c}-0.52 \\
0.01\end{array}$ & NS & $\begin{array}{c}0.64 \\
0.001\end{array}$ & NS & $\begin{array}{l}-0.62 \\
0.002\end{array}$ & NS & NS & NS & NS \\
\hline AIVIAB & NS & NS & NS & $\begin{array}{c}-0.44 \\
0.04\end{array}$ & NS & NS & NS & $\begin{array}{c}-0.44 \\
0.04\end{array}$ & NS & $\begin{array}{r}-0.50 \\
0.02\end{array}$ & NS & NS \\
\hline Al & $\begin{array}{c}0.76 \\
0.0001\end{array}$ & $\begin{array}{l}0.52 \\
0.01\end{array}$ & NS & NS & $\begin{array}{c}0.81 \\
0.0001\end{array}$ & $\begin{array}{c}0.70 \\
0.0003\end{array}$ & NS & NS & NS & NS & NS & NS \\
\hline VIAB & NS & NS & NS & $\begin{array}{c}-0.48 \\
0.02\end{array}$ & NS & NS & NS & $\begin{array}{c}-0.45 \\
0.04\end{array}$ & NS & $\begin{array}{l}-0.47 \\
0.03\end{array}$ & NS & NS \\
\hline COMP & $\begin{array}{c}-0.50 \\
0.02\end{array}$ & $\begin{array}{c}-0.51 \\
0.02\end{array}$ & NS & $\begin{array}{c}0.77 \\
0.0001\end{array}$ & NS & $\begin{array}{c}-0.52 \\
0.01\end{array}$ & NS & $\begin{array}{c}0.54 \\
0.009\end{array}$ & NS & NS & NS & NS \\
\hline
\end{tabular}

${ }^{\S} \mathrm{LE}=\mathrm{E}-\mathrm{Z}$ Freezin ${ }^{\mathrm{TM}}$ "LE" semen extender.

SLOW $=$ semen frozen using static vapor with a slow pre-freeze cooling rate applied.

INRA $96=$ INRA 96 semen extender used as post-thaw diluent.

${ }^{\mathrm{a}} \mathrm{T} 0=$ Fresh semen evaluated prior to cooling.

${ }^{\mathrm{b}}$ T24 = Semen stored in an Equitainer ${ }^{\circledR}$ for 24 hours.

${ }^{\mathrm{c}}$ DIFF $=$ Difference between $\mathrm{T} 0$ and $\mathrm{T} 24$. 
Table 10. Correlation coefficients and p-values for fresh semen total motility (T0-MOT; \%) and post-thaw semen measures for stallion spermatozoa.

\begin{tabular}{|c|c|c|c|c|c|c|c|c|}
\hline & $\begin{array}{l}\text { LE } \\
\text { SLOW } \\
\text { LE }\end{array}$ & $\begin{array}{l}\text { LE } \\
\text { SLOW } \\
\text { INRA }\end{array}$ & $\begin{array}{l}\text { LE } \\
\text { FAST } \\
\text { LE }\end{array}$ & $\begin{array}{l}\text { LE } \\
\text { FAST } \\
\text { INRA }\end{array}$ & $\begin{array}{l}\text { MF } \\
\text { SLOW } \\
\text { MF }\end{array}$ & $\begin{array}{l}\text { MF } \\
\text { SLOW } \\
\text { INRA }\end{array}$ & $\begin{array}{l}\text { MF } \\
\text { FAST } \\
\text { MF }\end{array}$ & $\begin{array}{l}\text { MF } \\
\text { FAST } \\
\text { INRA }\end{array}$ \\
\hline MOT & $\begin{array}{c}0.56 \\
(0.007)\end{array}$ & $\begin{array}{l}0.50 \\
(0.02)\end{array}$ & NS & NS & NS & NS & NS & NS \\
\hline PMOT & NS & $\begin{array}{l}0.51 \\
(0.01)\end{array}$ & NS & NS & NS & NS & NS & NS \\
\hline VCL & NS & NS & NS & NS & NS & NS & NS & NS \\
\hline VAP & NS & NS & NS & NS & NS & NS & NS & NS \\
\hline VSL & NS & NS & NS & NS & NS & NS & NS & NS \\
\hline LIN & NS & NS & NS & NS & NS & NS & NS & NS \\
\hline AIVIAB & NS & NS & NS & NS & NS & NS & NS & NS \\
\hline $\mathrm{AI}$ & $\begin{array}{c}0.59 \\
(0.004)\end{array}$ & $\begin{array}{c}0.76 \\
(0.0001)\end{array}$ & $\begin{array}{l}0.60 \\
(0.005)\end{array}$ & $\begin{array}{c}0.65 \\
(0.002)\end{array}$ & $\begin{array}{c}0.67 \\
(0.0007)\end{array}$ & $\begin{array}{c}0.70 \\
(0.0003)\end{array}$ & NS & NS \\
\hline VIAB & $\begin{array}{l}0.44 \\
(0.04)\end{array}$ & NS & NS & NS & NS & NS & NS & NS \\
\hline COMP & $\begin{array}{c}-0.50 \\
(0.01)\end{array}$ & $\begin{array}{r}-0.50 \\
(0.02)\end{array}$ & $\begin{array}{c}-0.50 \\
(0.03)\end{array}$ & $\begin{array}{r}-0.50 \\
(0.03)\end{array}$ & NS & NS & NS & NS \\
\hline
\end{tabular}

${ }^{\S} \mathrm{LE} / \mathrm{SLOW} / \mathrm{LE}=$ treatment group where semen was frozen using E-Z Freezin ${ }^{\mathrm{TM}}$ "LE" semen extender, applied a slow pre-freeze cooling rate, and diluted in E-Z Freezin "LM "LE" semen extender for post-thaw analysis.

LE/SLOW/INRA = treatment group where semen was frozen using E-Z Freezin " ${ }^{\mathrm{TM}}$ "LE" semen extender, applied a slow pre-freeze cooling rate, and diluted in INRA 96 semen extender for post-thaw analysis.

$\mathrm{LE} / \mathrm{FAST} / \mathrm{LE}=$ treatment group where semen was frozen using E-Z Freezin ${ }^{\mathrm{TM}}$ "LE" semen extender, applied a fast pre-freeze cooling rate, and diluted in E-Z Freezin ${ }^{\mathrm{TM}}$ "LE" semen extender for post-thaw analysis. LE/FAST/INRA = treatment group where semen was frozen using E-Z Freezin ${ }^{\mathrm{TM}}$ "LE" semen extender, applied a fast pre-freeze cooling rate, and diluted in INRA 96 semen extender for post-thaw analysis. $\mathrm{MF} / \mathrm{SLOW} / \mathrm{MF}$ = treatment group where semen was frozen using E-Z Freezin "TM "MFR5" semen extender, applied a slow pre-freeze cooling rate, and diluted in E-Z Freezin "MFR5" semen extender for post-thaw analysis.

MF/SLOW/INRA = treatment group where semen was frozen using E-Z Freezin "TM "MFR5" semen extender, applied a slow pre-freeze cooling rate, and diluted in INRA 96 semen extender for post-thaw analysis.

$\mathrm{MF} / \mathrm{FAST} / \mathrm{MF}$ = treatment group where semen was frozen using E-Z Freezin ${ }^{\mathrm{TM}}$ "MFR5" semen extender, applied a fast pre-freeze cooling rate, and diluted in E-Z Freezin "TM "MFR5" semen extender for post-thaw analysis.

MF/FAST/INRA = treatment group where semen was frozen using E-Z Freezin ${ }^{\mathrm{TM}}$ "MFR5" semen extender, applied a fast pre-freeze cooling rate, and diluted in INRA 96 semen extender for post-thaw analysis. 
Table 11. Correlation coefficients and $p$-values for fresh semen progressive motility (T0-PMOT; \%) and post-thaw semen measures for stallion spermatozoa.

\begin{tabular}{|c|c|c|c|c|c|c|c|c|}
\hline & $\begin{array}{l}\text { LE } \\
\text { SLOW } \\
\text { LE }\end{array}$ & $\begin{array}{l}\text { LE } \\
\text { SLOW } \\
\text { INRA }\end{array}$ & $\begin{array}{l}\text { LE } \\
\text { FAST } \\
\text { LE }\end{array}$ & $\begin{array}{l}\text { LE } \\
\text { FAST } \\
\text { INRA }\end{array}$ & $\begin{array}{l}\text { MF } \\
\text { SLOW } \\
\text { MF }\end{array}$ & $\begin{array}{l}\text { MF } \\
\text { SLOW } \\
\text { INRA }\end{array}$ & $\begin{array}{l}\text { MF } \\
\text { FAST } \\
\text { MF }\end{array}$ & $\begin{array}{l}\text { MF } \\
\text { FAST } \\
\text { INRA }\end{array}$ \\
\hline MOT & $\begin{array}{c}0.57 \\
(0.006)\end{array}$ & $\begin{array}{l}0.45 \\
(0.03)\end{array}$ & NS & NS & NS & NS & NS & NS \\
\hline PMOT & NS & $\begin{array}{l}0.44 \\
(0.04)\end{array}$ & NS & NS & NS & NS & NS & NS \\
\hline VCL & NS & NS & NS & NS & NS & NS & NS & NS \\
\hline VAP & NS & NS & NS & NS & NS & NS & NS & NS \\
\hline VSL & NS & NS & NS & NS & NS & NS & NS & NS \\
\hline LIN & $\begin{array}{l}0.53 \\
(0.01)\end{array}$ & $\begin{array}{l}0.48 \\
(0.02)\end{array}$ & NS & $\begin{array}{c}0.72 \\
(0.0003)\end{array}$ & $\begin{array}{c}0.61 \\
(0.002)\end{array}$ & NS & NS & NS \\
\hline AIVIAB & NS & NS & NS & NS & NS & NS & $\begin{array}{c}-0.46 \\
(0.04)\end{array}$ & NS \\
\hline $\mathrm{AI}$ & NS & $\begin{array}{l}0.52 \\
(0.01)\end{array}$ & NS & $\begin{array}{l}0.48 \\
(0.03)\end{array}$ & NS & $\begin{array}{l}0.46 \\
(0.03)\end{array}$ & NS & NS \\
\hline VIAB & NS & NS & NS & NS & NS & NS & $\begin{array}{c}-0.46 \\
(0.04)\end{array}$ & NS \\
\hline COMP & $\begin{array}{c}-0.51 \\
(0.02)\end{array}$ & $\begin{array}{c}-0.51 \\
(0.02)\end{array}$ & $\begin{array}{l}-0.63 \\
(0.003)\end{array}$ & $\begin{array}{l}-0.63 \\
(0.003)\end{array}$ & NS & NS & NS & NS \\
\hline
\end{tabular}


Table 12. Correlation coefficients and $\mathrm{p}$-values for fresh semen curvilinear velocity $(\mathrm{T} 0-\mathrm{VCL} ; \mu \mathrm{m} / \mathrm{s})$ and post-thaw semen measures for stallion spermatozoa.

\begin{tabular}{|c|c|c|c|c|c|c|c|c|}
\hline & & & & & $-\mathrm{VCL}$ & & & \\
\hline & $\begin{array}{l}\text { LE } \\
\text { SLOW } \\
\text { LE }\end{array}$ & $\begin{array}{l}\text { LE } \\
\text { SLOW } \\
\text { INRA }\end{array}$ & $\begin{array}{l}\text { LE } \\
\text { FAST } \\
\text { LE }\end{array}$ & $\begin{array}{l}\text { LE } \\
\text { FAST } \\
\text { INRA }\end{array}$ & $\begin{array}{l}\text { MF } \\
\text { SLOW } \\
\text { MF }\end{array}$ & $\begin{array}{l}\text { MF } \\
\text { SLOW } \\
\text { INRA }\end{array}$ & $\begin{array}{l}\text { MF } \\
\text { FAST } \\
\text { MF }\end{array}$ & $\begin{array}{l}\text { MF } \\
\text { FAST } \\
\text { INRA }\end{array}$ \\
\hline MOT & NS & NS & NS & NS & NS & NS & NS & NS \\
\hline PMOT & NS & NS & NS & NS & NS & NS & NS & NS \\
\hline VCL & NS & $\begin{array}{c}0.43 \\
(0.045)\end{array}$ & NS & NS & NS & $\begin{array}{l}0.47 \\
(0.03)\end{array}$ & NS & NS \\
\hline VAP & NS & NS & NS & NS & NS & NS & NS & NS \\
\hline VSL & NS & NS & NS & NS & NS & NS & NS & NS \\
\hline LIN & $\begin{array}{l}-0.61 \\
(0.003)\end{array}$ & $\begin{array}{l}-0.43 \\
(0.04)\end{array}$ & $\begin{array}{r}-0.56 \\
(0.01)\end{array}$ & NS & $\begin{array}{c}-0.66 \\
(0.0008)\end{array}$ & $\begin{array}{l}-0.49 \\
(0.02)\end{array}$ & NS & $\begin{array}{r}-0.55 \\
(0.01)\end{array}$ \\
\hline AIVIAB & NS & NS & $\begin{array}{c}-0.48 \\
(0.03)\end{array}$ & NS & NS & NS & NS & NS \\
\hline $\mathrm{AI}$ & NS & NS & NS & NS & NS & NS & NS & NS \\
\hline VIAB & NS & NS & NS & NS & NS & NS & NS & NS \\
\hline COMP & NS & NS & NS & NS & NS & NS & NS & NS \\
\hline
\end{tabular}


Table 13. Correlation coefficients and p-values for fresh semen chromatin (T0-COMP; \%) and post-thaw semen measures for stallion spermatozoa.

\begin{tabular}{|c|c|c|c|c|c|c|c|c|}
\hline & $\begin{array}{l}\text { LE } \\
\text { SLOW } \\
\text { LE }\end{array}$ & $\begin{array}{l}\text { LE } \\
\text { SLOW } \\
\text { INRA }\end{array}$ & $\begin{array}{l}\text { LE } \\
\text { FAST } \\
\text { LE }\end{array}$ & $\begin{array}{l}\text { LE } \\
\text { FAST } \\
\text { INRA }\end{array}$ & $\begin{array}{l}\text { MF } \\
\text { SLOW } \\
\text { MF }\end{array}$ & $\begin{array}{l}\text { MF } \\
\text { SLOW } \\
\text { INRA }\end{array}$ & \begin{tabular}{|l|} 
MF \\
FAST \\
MF
\end{tabular} & $\begin{array}{l}\text { MF } \\
\text { FAST } \\
\text { INRA }\end{array}$ \\
\hline MOT & NS & $\begin{array}{l}-0.47 \\
(0.03)\end{array}$ & NS & NS & NS & NS & NS & NS \\
\hline PMOT & NS & NS & NS & NS & NS & NS & NS & NS \\
\hline VCL & NS & NS & NS & NS & NS & NS & NS & NS \\
\hline VAP & NS & NS & NS & NS & NS & NS & NS & NS \\
\hline VSL & NS & NS & NS & NS & NS & NS & NS & NS \\
\hline LIN & NS & $\begin{array}{c}-0.52 \\
(0.01)\end{array}$ & NS & $\begin{array}{l}-0.53 \\
(0.02)\end{array}$ & NS & NS & NS & NS \\
\hline AIVIAB & $\begin{array}{l}-0.45 \\
(0.04)\end{array}$ & $\begin{array}{l}-0.44 \\
(0.04)\end{array}$ & NS & NS & NS & NS & NS & NS \\
\hline AI & NS & NS & NS & NS & NS & NS & NS & NS \\
\hline VIAB & $\begin{array}{l}-0.55 \\
(0.008)\end{array}$ & $\begin{array}{l}-0.48 \\
(0.02)\end{array}$ & NS & NS & NS & NS & NS & NS \\
\hline COMP & $\begin{array}{c}0.77 \\
(0.0001)\end{array}$ & $\begin{array}{c}0.77 \\
(0.0001)\end{array}$ & NS & NS & $\begin{array}{c}0.64 \\
(0.001)\end{array}$ & $\begin{array}{c}0.64 \\
(0.001)\end{array}$ & $\begin{array}{c}0.67 \\
(0.001)\end{array}$ & $\begin{array}{c}0.67 \\
(0.001)\end{array}$ \\
\hline
\end{tabular}


Table 14. Correlation coefficients and p-values for cooled semen total motility (T24-MOT; \%) and post-thaw semen measures for stallion spermatozoa.

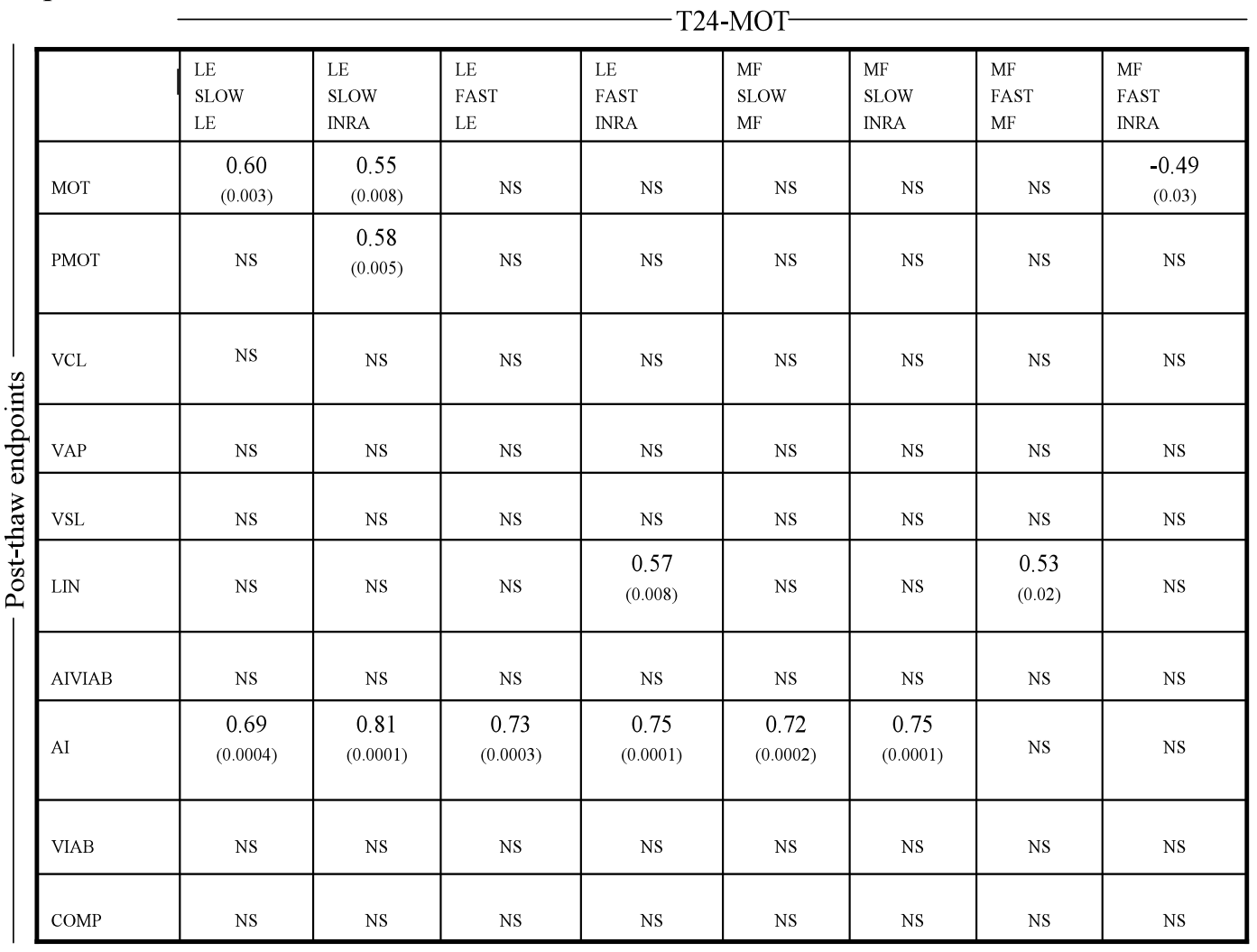


Table 15. Correlation coefficients and p-values for cooled semen progressive motility (T24-PMOT; \%) and post-thaw semen measures for stallion spermatozoa.

\begin{tabular}{|c|c|c|c|c|c|c|c|c|}
\hline & $\begin{array}{l}\text { LE } \\
\text { SLOW } \\
\text { LE }\end{array}$ & $\begin{array}{l}\text { LE } \\
\text { SLOW } \\
\text { INRA }\end{array}$ & $\begin{array}{l}\text { LE } \\
\text { FAST } \\
\text { LE }\end{array}$ & $\begin{array}{l}\text { LE } \\
\text { FAST } \\
\text { INRA }\end{array}$ & $\begin{array}{l}\text { MF } \\
\text { SLOW } \\
\text { MF }\end{array}$ & $\begin{array}{l}\text { MF } \\
\text { SLOW } \\
\text { INRA }\end{array}$ & $\begin{array}{l}\text { MF } \\
\text { FAST } \\
\text { MF }\end{array}$ & $\begin{array}{l}\text { MF } \\
\text { FAST } \\
\text { INRA }\end{array}$ \\
\hline MOT & $\begin{array}{c}0.62 \\
(0.002)\end{array}$ & $\begin{array}{l}0.53 \\
(0.01)\end{array}$ & NS & NS & NS & NS & NS & NS \\
\hline PMOT & NS & $\begin{array}{c}0.56 \\
(0.007)\end{array}$ & NS & NS & NS & NS & NS & NS \\
\hline VCL & NS & $\begin{array}{r}-0.43 \\
(0.04)\end{array}$ & $\begin{array}{l}-0.45 \\
(0.04)\end{array}$ & NS & NS & NS & NS & NS \\
\hline VAP & NS & NS & NS & NS & NS & NS & NS & NS \\
\hline VSL & NS & NS & NS & NS & NS & NS & NS & NS \\
\hline LIN & $\begin{array}{c}0.63 \\
(0.002)\end{array}$ & $\begin{array}{c}0.64 \\
(0.001)\end{array}$ & $\begin{array}{l}0.50 \\
(0.02)\end{array}$ & $\begin{array}{c}0.80 \\
(0.0001)\end{array}$ & $\begin{array}{c}0.65 \\
(0.001)\end{array}$ & $\begin{array}{c}0.56 \\
(0.006)\end{array}$ & NS & $\begin{array}{l}0.52 \\
(0.02)\end{array}$ \\
\hline AIVIAB & $\begin{array}{l}0.47 \\
(0.03)\end{array}$ & NS & NS & NS & NS & NS & NS & NS \\
\hline $\mathrm{AI}$ & $\begin{array}{c}0.61 \\
(0.003)\end{array}$ & $\begin{array}{c}0.70 \\
(0.0003)\end{array}$ & $\begin{array}{c}0.65 \\
(0.002)\end{array}$ & $\begin{array}{c}0.70 \\
(0.0006)\end{array}$ & $\begin{array}{c}0.55 \\
(0.007)\end{array}$ & $\begin{array}{c}0.60 \\
(0.003)\end{array}$ & NS & NS \\
\hline VIAB & $\begin{array}{l}0.52 \\
(0.01)\end{array}$ & NS & NS & NS & NS & NS & NS & NS \\
\hline COMP & $\begin{array}{c}-0.52 \\
(0.01)\end{array}$ & $\begin{array}{c}-0.52 \\
(0.01)\end{array}$ & $\begin{array}{c}-0.54 \\
(0.01)\end{array}$ & $\begin{array}{c}-0.54 \\
(0.01)\end{array}$ & NS & NS & $\begin{array}{c}-0.46 \\
(0.04)\end{array}$ & $\begin{array}{c}-0.46 \\
(0.04)\end{array}$ \\
\hline
\end{tabular}


Table 16. Correlation coefficients and p-values for cooled semen curvilinear velocity (T24-VCL; $\mu \mathrm{m} / \mathrm{s}$ ) and post-thaw semen measures for stallion spermatozoa.

\begin{tabular}{|c|c|c|c|c|c|c|c|c|}
\hline & \multicolumn{8}{|c|}{$\mathrm{T} 24-\mathrm{VCL}-$} \\
\hline & $\begin{array}{l}\text { LE } \\
\text { SLOW } \\
\text { LE }\end{array}$ & $\begin{array}{l}\text { LE } \\
\text { SLOW } \\
\text { INRA }\end{array}$ & $\begin{array}{l}\text { LE } \\
\text { FAST } \\
\text { LE }\end{array}$ & $\begin{array}{l}\text { LE } \\
\text { FAST } \\
\text { INRA } \\
\end{array}$ & $\begin{array}{l}\text { MF } \\
\text { SLOW } \\
\text { MF } \\
\end{array}$ & $\begin{array}{l}\text { MF } \\
\text { SLOW } \\
\text { INRA } \\
\end{array}$ & $\begin{array}{l}\text { MF } \\
\text { FAST } \\
\text { MF } \\
\end{array}$ & $\begin{array}{l}\text { MF } \\
\text { FAST } \\
\text { INRA } \\
\end{array}$ \\
\hline MOT & NS & NS & NS & NS & NS & NS & NS & NS \\
\hline PMOT & NS & NS & NS & NS & NS & NS & NS & NS \\
\hline $\mathrm{VCL}$ & $\begin{array}{c}0.60 \\
(0.003)\end{array}$ & $\begin{array}{c}0.74 \\
(0.0001)\end{array}$ & $\begin{array}{l}0.51 \\
(0.02)\end{array}$ & $\begin{array}{c}0.66 \\
(0.002)\end{array}$ & $\begin{array}{c}0.57 \\
(0.005)\end{array}$ & $\begin{array}{c}0.75 \\
(0.0001)\end{array}$ & NS & $\begin{array}{c}0.70 \\
(0.0005)\end{array}$ \\
\hline VAP & $\begin{array}{l}0.44 \\
(0.04) \\
\end{array}$ & $\begin{array}{c}0.65 \\
(0.001) \\
\end{array}$ & NS & $\begin{array}{c}0.61 \\
(0.004) \\
\end{array}$ & NS & $\begin{array}{c}0.66 \\
(0.0009) \\
\end{array}$ & NS & $\begin{array}{c}0.63 \\
(0.003)\end{array}$ \\
\hline VSL & NS & $\begin{array}{c}0.54 \\
(0.009) \\
\end{array}$ & NS & $\begin{array}{r}0.51 \\
(0.02) \\
\end{array}$ & NS & $\begin{array}{c}0.56 \\
(0.007) \\
\end{array}$ & NS & NS \\
\hline LIN & $\begin{array}{l}-0.64 \\
(0.001)\end{array}$ & NS & $\begin{array}{l}-0.58 \\
(0.008)\end{array}$ & NS & $\begin{array}{l}-0.45 \\
(0.03)\end{array}$ & $\begin{array}{l}-0.57 \\
(0.006)\end{array}$ & NS & $\begin{array}{l}-0.68 \\
(0.001)\end{array}$ \\
\hline AIVIAB & NS & NS & NS & NS & NS & NS & NS & NS \\
\hline AI & NS & NS & NS & NS & NS & NS & NS & NS \\
\hline VIAB & NS & NS & NS & NS & NS & NS & NS & NS \\
\hline COMP & NS & NS & NS & NS & NS & NS & NS & NS \\
\hline
\end{tabular}


Table 17. Correlation coefficients and $\mathrm{p}$-values for cooled semen chromatin (T24-COMP; \%) and post-thaw semen measures for stallion spermatozoa.

\begin{tabular}{|c|c|c|c|c|c|c|c|c|}
\hline & $\begin{array}{l}\text { LE } \\
\text { SLOW } \\
\text { LE }\end{array}$ & $\begin{array}{l}\text { LE } \\
\text { SLOW } \\
\text { INRA }\end{array}$ & $\begin{array}{l}\text { LE } \\
\text { FAST } \\
\text { LE }\end{array}$ & $\begin{array}{l}\text { LE } \\
\text { FAST } \\
\text { INRA }\end{array}$ & $\begin{array}{l}\text { MF } \\
\text { SLOW } \\
\text { MF }\end{array}$ & $\begin{array}{l}\text { MF } \\
\text { SLOW } \\
\text { INRA }\end{array}$ & $\begin{array}{l}\text { MF } \\
\text { FAST } \\
\text { MF }\end{array}$ & $\begin{array}{l}\text { MF } \\
\text { FAST } \\
\text { INRA }\end{array}$ \\
\hline MOT & NS & NS & NS & NS & NS & NS & NS & NS \\
\hline PMOT & NS & $\begin{array}{r}-0.47 \\
(0.03)\end{array}$ & NS & NS & NS & NS & NS & NS \\
\hline $\mathrm{VCL}$ & NS & NS & NS & NS & NS & NS & NS & NS \\
\hline VAP & NS & $\begin{array}{c}-0.46 \\
(0.03)\end{array}$ & NS & NS & NS & NS & $\begin{array}{r}-0.50 \\
(0.02)\end{array}$ & NS \\
\hline VSL & NS & $\begin{array}{l}-0.54 \\
(0.009)\end{array}$ & NS & NS & NS & NS & $\begin{array}{r}-0.55 \\
(0.01)\end{array}$ & NS \\
\hline LIN & NS & $\begin{array}{l}-0.62 \\
(0.002)\end{array}$ & NS & NS & NS & NS & NS & NS \\
\hline AIVIAB & $\begin{array}{c}-0.48 \\
(0.02)\end{array}$ & $\begin{array}{c}-0.44 \\
(0.04)\end{array}$ & NS & NS & NS & NS & NS & NS \\
\hline AI & NS & NS & NS & NS & NS & NS & NS & NS \\
\hline VIAB & $\begin{array}{c}-0.54 \\
(0.0089)\end{array}$ & $\begin{array}{l}-0.45 \\
(0.04)\end{array}$ & NS & NS & NS & NS & NS & NS \\
\hline COMP & $\begin{array}{c}0.54 \\
(0.0093)\end{array}$ & $\begin{array}{c}0.54 \\
(0.009)\end{array}$ & NS & NS & $\begin{array}{c}0.70 \\
(0.0003)\end{array}$ & $\begin{array}{c}0.70 \\
(0.0003)\end{array}$ & $\begin{array}{l}0.50 \\
(0.02)\end{array}$ & $\begin{array}{l}0.50 \\
(0.02)\end{array}$ \\
\hline
\end{tabular}


Table 18. Correlation coefficients and $p$-values for fresh/cooled semen total motility \% change (DIFF-MOT; \%) and post-thaw semen measures for stallion spermatozoa.

\begin{tabular}{|c|c|c|c|c|c|c|c|c|}
\hline & $\begin{array}{l}\text { LE } \\
\text { SLOW } \\
\text { LE }\end{array}$ & $\begin{array}{l}\text { LE } \\
\text { SLOW } \\
\text { INRA }\end{array}$ & $\begin{array}{l}\text { LE } \\
\text { FAST } \\
\text { LE }\end{array}$ & $\begin{array}{l}\text { LE } \\
\text { FAST } \\
\text { INRA }\end{array}$ & $\begin{array}{l}\text { MF } \\
\text { SLOW } \\
\text { MF }\end{array}$ & $\begin{array}{l}\text { MF } \\
\text { SLOW } \\
\text { INRA }\end{array}$ & $\begin{array}{l}\text { MF } \\
\text { FAST } \\
\text { MF }\end{array}$ & $\begin{array}{l}\text { MF } \\
\text { FAST } \\
\text { INRA }\end{array}$ \\
\hline MOT & NS & NS & NS & NS & NS & NS & NS & NS \\
\hline PMOT & NS & NS & NS & NS & NS & NS & NS & NS \\
\hline $\mathrm{VCL}$ & NS & NS & NS & NS & NS & NS & NS & NS \\
\hline VAP & NS & NS & NS & NS & NS & NS & NS & NS \\
\hline VSL & NS & NS & NS & NS & NS & NS & NS & NS \\
\hline LIN & NS & NS & NS & NS & NS & NS & NS & NS \\
\hline AIVIAB & NS & NS & NS & NS & NS & NS & NS & NS \\
\hline AI & NS & NS & NS & NS & NS & NS & NS & NS \\
\hline VIAB & NS & NS & NS & NS & NS & NS & NS & NS \\
\hline COMP & NS & NS & NS & NS & NS & NS & NS & NS \\
\hline
\end{tabular}


Table 19. Correlation coefficients and p-values for fresh/cooled semen progressive motility \% change (DIFF-MOT; \%) and post-thaw semen measures for stallion spermatozoa.

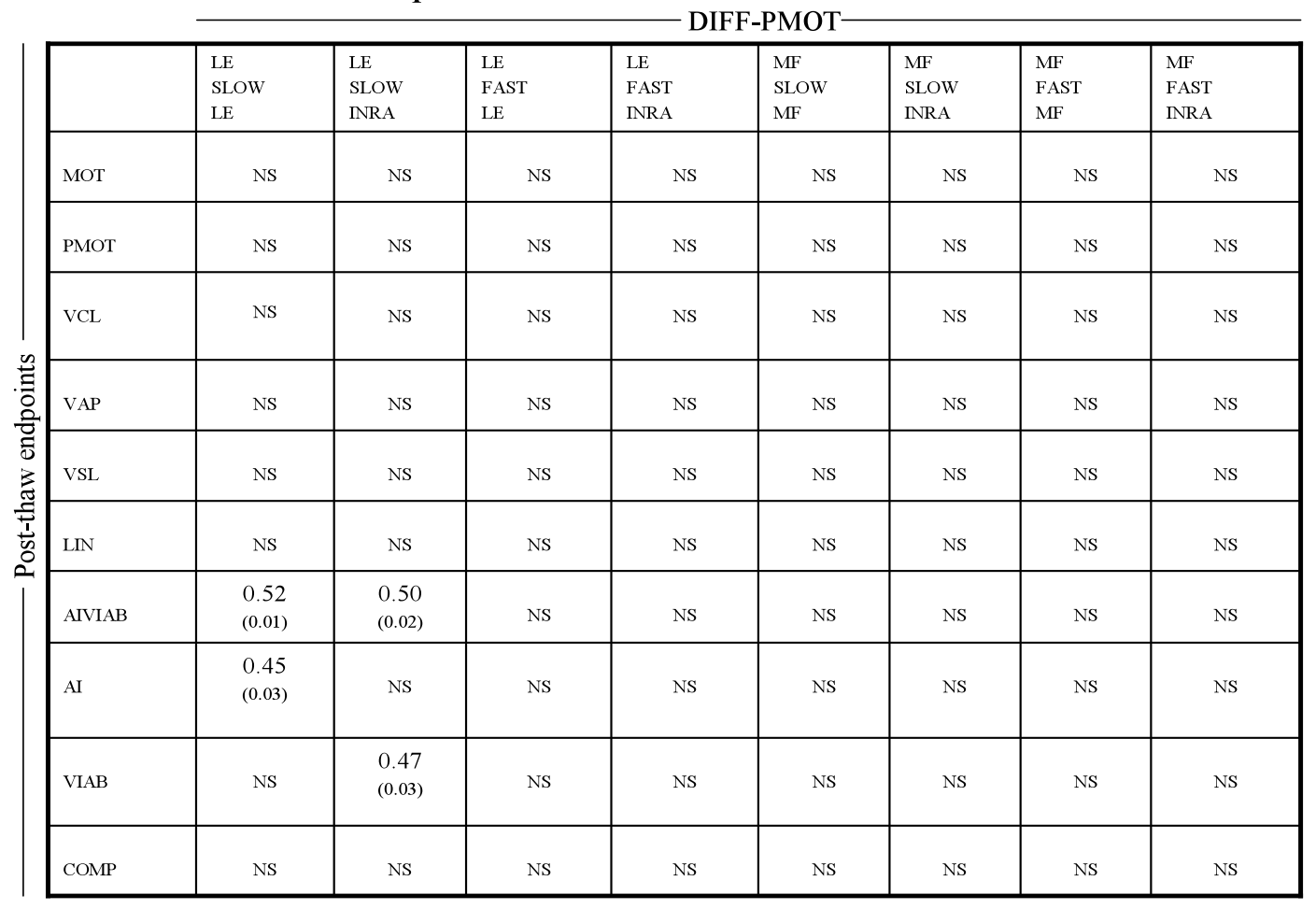


Table 20. Correlation coefficients and $p$-values for fresh/cooled semen curvilinear velocity $\%$ change (DIFF-VCL; $\mu \mathrm{m} / \mathrm{s}$ ) and post-thaw semen measures for stallion spermatozoa.

\begin{tabular}{|c|c|c|c|c|c|c|c|c|}
\hline & $\begin{array}{l}\text { LE } \\
\text { SLOW } \\
\text { LE }\end{array}$ & $\begin{array}{l}\text { LE } \\
\text { SLOW } \\
\text { INRA }\end{array}$ & $\begin{array}{l}\text { LE } \\
\text { FAST } \\
\text { LE }\end{array}$ & $\begin{array}{l}\text { LE } \\
\text { FAST } \\
\text { INRA }\end{array}$ & $\begin{array}{l}\text { MF } \\
\text { SLOW } \\
\text { MF }\end{array}$ & $\begin{array}{l}\text { MF } \\
\text { SLOW } \\
\text { INRA }\end{array}$ & $\begin{array}{l}\text { MF } \\
\text { FAST } \\
\text { MF }\end{array}$ & $\begin{array}{l}\text { MF } \\
\text { FAST } \\
\text { INRA }\end{array}$ \\
\hline MOT & NS & NS & NS & NS & NS & NS & NS & NS \\
\hline PMOT & NS & NS & NS & NS & NS & NS & NS & NS \\
\hline $\mathrm{VCL}$ & $\begin{array}{l}0.46 \\
(0.03)\end{array}$ & $\begin{array}{l}0.43 \\
(0.04)\end{array}$ & NS & NS & NS & $\begin{array}{l}0.48 \\
(0.03)\end{array}$ & NS & $\begin{array}{l}0.51 \\
(0.02)\end{array}$ \\
\hline VAP & $\begin{array}{l}0.48 \\
(0.02)\end{array}$ & $\begin{array}{l}0.44 \\
(0.04)\end{array}$ & NS & NS & $\begin{array}{l}0.48 \\
(0.02)\end{array}$ & $\begin{array}{l}0.47 \\
(0.03)\end{array}$ & NS & $\begin{array}{l}0.53 \\
(0.02)\end{array}$ \\
\hline VSL & $\begin{array}{l}0.48 \\
(0.02)\end{array}$ & $\begin{array}{l}0.45 \\
(0.03)\end{array}$ & NS & NS & $\begin{array}{l}0.49 \\
(0.02)\end{array}$ & $\begin{array}{l}0.47 \\
(0.03)\end{array}$ & NS & NS \\
\hline LIN & NS & NS & NS & NS & NS & NS & NS & NS \\
\hline AIVIAB & NS & NS & NS & NS & NS & NS & NS & NS \\
\hline AI & NS & NS & NS & NS & NS & NS & NS & NS \\
\hline VIAB & NS & NS & NS & NS & NS & NS & NS & NS \\
\hline COMP & NS & NS & NS & NS & $\begin{array}{r}-0.45 \\
(0.03)\end{array}$ & $\begin{array}{c}-0.45 \\
(0.03)\end{array}$ & NS & NS \\
\hline
\end{tabular}


Table 21. Correlation coefficients and p-values for fresh/cooled semen chromatin $\%$ change (DIFF-COMP; \%) and post-thaw semen measures for stallion spermatozoa.

\begin{tabular}{|c|c|c|c|c|c|c|c|c|}
\hline & $\begin{array}{l}\text { LE } \\
\text { SLOW } \\
\text { LE }\end{array}$ & $\begin{array}{l}\text { LE } \\
\text { SLOW } \\
\text { INRA }\end{array}$ & $\begin{array}{l}\text { LE } \\
\text { FAST } \\
\text { LE }\end{array}$ & $\begin{array}{l}\text { LE } \\
\text { FAST } \\
\text { INRA }\end{array}$ & $\begin{array}{l}\text { MF } \\
\text { SLOW } \\
\text { MF }\end{array}$ & $\begin{array}{l}\text { MF } \\
\text { SLOW } \\
\text { INRA }\end{array}$ & $\begin{array}{l}\text { MF } \\
\text { FAST } \\
\text { MF }\end{array}$ & $\begin{array}{l}\text { MF } \\
\text { FAST } \\
\text { INRA }\end{array}$ \\
\hline MOT & NS & NS & NS & NS & NS & NS & NS & NS \\
\hline РMOT & NS & NS & NS & NS & NS & NS & NS & NS \\
\hline VCL & NS & NS & NS & NS & NS & NS & NS & NS \\
\hline VAP & NS & NS & NS & NS & NS & NS & NS & NS \\
\hline VSL & NS & NS & NS & NS & NS & NS & NS & NS \\
\hline LIN & NS & NS & NS & NS & NS & NS & NS & NS \\
\hline AIVIAB & NS & NS & NS & NS & NS & NS & NS & NS \\
\hline AI & NS & NS & NS & NS & NS & NS & NS & NS \\
\hline VIAB & NS & NS & NS & NS & NS & NS & NS & NS \\
\hline COMP & NS & NS & NS & NS & NS & NS & NS & NS \\
\hline
\end{tabular}




\section{DISCUSSION AND SUMMARY}

Several groups have reported optimal cooling rates and storage temperatures for maximizing the viability and fertilizing capacity of cool-stored spermatozoa [3,37-50]. Only limited information, however, is available regarding the effects of a pre-freeze cooling rate on equine semen subjected to cryopreservation $[1,14]$. Data evolving from cooled-semen trials indicate that equine spermatozoa are tolerant of rapid cooling rates to approximately $20{ }^{\circ} \mathrm{C}$, but become susceptible to injury when rapid cooling rates are applied to temperatures between $20{ }^{\circ} \mathrm{C}$ and $4{ }^{\circ} \mathrm{C}$ [44]. Such injury is attributable to disruption in membrane functional states resulting from phase separation events in lipid bilayers [51-53] and alterations in water transport properties [54]. This study was conducted to evaluate the effect of two freezing extender types and two pre-freeze cooling rates on post-thaw spermatozoal function.

Our experimental data indicate that LE extender provided superior results to MFR5 extender when used for cryopreservation of semen from eight experimental stallions. In addition, a slower pre-freeze cooling rate also yielded better results than a fast pre-freeze cooling rate, based on several post-thaw spermatozoal characteristics with the LE-SLOW treatment ranking highest, when compared to the other three treatments. This finding contradicts unpublished claims that milk-based freezing extender provides better results when a slow pre-freeze cooling rate is applied, but that post-thaw viability of spermatozoa in egg yolk-based extender might be optimized when using a fast pre- 
freeze cooling rate [15]. Standardization and reduction of the glycerol concentration to $2.5 \%(\mathrm{v} / \mathrm{v})$ in both LE and MFR5 may have led to the similar response of spermatozoa in these two extender types of pre-freeze cooling conditions. Although this glycerol concentration is consistent with recent recommendations in the literature $[5,11,19]$, previous studies have been conducted with glycerol concentration in the range of 4-5\% [1,18], and MFR5 and LE extenders are currently available commercially with glycerol concentrations usually set at $4 \%$ and $4.75 \%$, respectively (Animal Reproduction Systems, personal communication). The slow pre-freeze cooling rate allows for a gradual decrease in storage temperature to approximately $4{ }^{\circ} \mathrm{C}$, thus reducing the potentially detrimental effects of cold shock on spermatozoal membranous structures [37,40]. Application of a slow cooling rate before freezing, combined with an increased concentration of egg yolk in LE extender (20\%), as opposed to MFR5 extender (3\%) may have increased the resistance of the outer acrosomal membrane and overlying plasma membrane to cooling and cryoinjury. Others have reported that the anterior segment of the stallion spermatozoal acrosome is the most susceptible to membranous damage following cold shock [55]. Additional reports reveal that acrosomal damage following cryopreservation is common in other mammalian species [56, 57], and that acrosomes may be more susceptible to cryoinjury when spermatozoa are exposed to increasingly higher glycerol concentrations [58]. In addition, a surfactant was incorporated into the LE extender but not the MRR5 extender. This may have improved 
emulsification and dispersion of egg yolk lipids, rendering them more readily available for interaction with the spermatozoal membranes [59].

Overall, when diluting the semen for post-thaw analysis, spermatozoal motility endpoints tended to be higher in semen diluted in a non-glycerol containing extender (ie, INRA 96), as compared to freezing medium (either LE or MFR5). The effects were more pronounced for semen cryopreserved in MF extender. Flow-cytometer endpoints, i.e., VIAB and AI, were not affected by post-thaw diluent to the same extent as were the CASMA variables. We had hypothesized that dilution of post-thaw semen in a glycerolfree isotonic medium would have a deleterious effect on measures of spermatozoal quality, because of a sudden change in the osmotic environment. Such exposure does not appear to be detrimental, based on the laboratory endpoints tested. Conversely, overall semen quality appeared to be improved when frozen-thawed semen was diluted in a glycerol-free medium. This data is supported by fertility trials conducted by Palmer [3].

As expected, T0 endpoints were highly correlated with the same experimental endpoints at T24 for cooled semen. Likewise, the CASMA values, MOT and PMOT for post-thaw data were highly correlated with the FC endpoints, AI, VIAB, and AIVIAB. Of interest, the correlations of PMOT and MOT to VIAB were higher than that for acrosomal integrity. Fiser and Fairfull (1990) reported that post-thaw motility and acrosomal integrity of boar spermatozoa, as measured by phase-contrast microscopy, 
were affected differently by alterations in cryopreservation technique. The differential response in these variables was most profound when glycerol concentration exceeded $3 \%$. In the present study, glycerol concentration was set at $2.5 \%$ for all experimental treatments; thereby reducing the potentially detrimental impact that glycerol could have on acrosomal integrity.

Cooled semen (T24) values for MOT, PMOT, VCL, and COMP were better predictors of spermatozoal resistance to cryoinjury than were initial (T0) values, based on the post-thaw variables tested. The percent change in the pre-freeze endpoints following cooled storage (DIFF) proved to be an ineffective predictor of spermatozoal "freezability". Interestingly, pre-freeze COMP yielded stronger linear correlations to post-thaw endpoints than did pre-freeze values for MOT, PMOT, or VCL.

In summary, these data indicate that spermatozoa of the eight stallions used in this study survived the freeze-thaw cycle better in egg-based extender than in milk-based extender when glycerol concentration was adjusted to $2.5 \%$. Although a stallion effect was detected, semen from all stallions performed better when mixed with LE extender, as opposed to MF extender, prior to cryopreservation. Regardless of freezing extender type, spermatozoa were more resistant to cryoinjury when subjected to a slow pre-freeze cooling rate, as opposed to immediate exposure to low cryopreservation temperatures. A non-glycerol-containing extender appears adequate for dilution of frozen-thawed semen prior to in-vitro analysis. Lastly, some pre-freeze measures of semen quality in our 
study had limited, but distinct, relevance to spermatozoal resistance to cryoinjury. More investigation is required to determine why the egg-based extender used in this study produced uniformly better results than the milk-based extender. 


\section{FUTURE AIMS}

While EZ Freezin "LE” semen extender appears to be superior to EZ Freezin "MFR5" the question remains as to exactly what components contribute to the improved post-thaw spermatozoal characteristics we observed. Perhaps removal of the surfactant that is incorporated in the "LE" extender and not the "MFR5" could explain the postthaw quality we observed. Additionally, the non-detrimental effects of using an isotonic medium (ie, INRA 96) as a post-thaw diluent were not expected. Although, in vitro analysis of post-thaw spermatozoal quality indicated "LE/SLOW/INRA" to be the best treatment group regarding freezability the ultimate test would be to subject spermatozoa to fertility trials and observe pregnancy rates. 


\section{REFERENCES}

1. Heitland AV, Jasko DJ, Squires EL, Graham JK, Pickett BW, Hamilton C. Factors affecting motion characteristics of frozen-thawed stallion spermatozoa. Equine Veterinary Journal 1996;28:47-53.

2. Samper J, Morris C. Current methods for stallion semen cryopreservation: A survey. Theriogenology 1998;49:895-903.

3. Palmer E. Factors affecting stallion semen survival and fertility. Proc. $10^{\text {th }}$ Inter. Congress on Anim.Reprod.and Artif. Insem. 1984; 377-379.

4. Martin JC, Klug E, Gunzel A-R. Centrifugation of stallion semen and its storage in large volume straws. J Reprod Fertil Suppl 1979;27:47-51.

5. Ecot P, Vidament M, de Mornac A, Perigault K, Clement F, Palmer E. Stallion frozen semen: interactions between cooling procedures, extenders, and stallions. J Reprod Fertil 2000; 52(Suppl.)

6. Braun J, Sakai M, Hochi S, Oguri N. Preservation of ejaculated and epididymal stallion spermatozoa by cooling and freezing. Theriogenology 1994;41:809-818.

7. Alghamdi AS, Troedsson MH, Xue JL, Crabo BG. Effect of seminal plasma concentration and various extenders on post-thaw motility and glass wool-Sephadex filtration of cryopreserved stallion semen. Am J Vet Res 2002;63:880-885.

8. Schembri MA, Major DA, Suttie JJ, Maxwell WM, Evans G. Modification of standard freezing media to limit capacitation and maximize motility of frozenthawed equine spermatozoa. Aust Vet J 2003;81:748-751.

9. Ecot P, Arnaud G, Moy A, Daels P, Magistrini M, Vidament M. Comparison of fertility and post-thaw semen criteria of stallion semen frozen in two different extenders. In: Squires EL, (Ed.) Proceedings of the $3^{\text {rd }}$ International Symposium on Stallion Reproduction. Anim Reprod Sci 2001;68:356-358.

10. Vidament M. French field results (1985-2005) on factors affecting fertility of frozen stallion semen. Anim Reprod Sci 2005;89:115-136. 
11. Vidamant M, Yvon JM, Couty I, Arnaud G, Nguekam-Feugang J, Noue P, Cottron S, Le Tellier A, Noel F, Palmer E, Magistrini M. Advances in cryopreservation of stallion semen in modified INRA82. Animal Reproduction Science 2001;68:201-218.

12. Moran DM, Jasko DJ, Squires EL, Amann RP. Determination of temperature and cooling rate which induce cold-shock in stallion spermatozoa. Theriogenology 1992;38:291-304.

13. Kayser JP, Amann RP, Shideler RK, Squires EL, Jasko DJ, Pickett BW. Effects of linear cooling rate on motion characteristics of stallion spermatozoa. Theriogenology 1992;38:601-614.

14. Vidamant M, Ecot P, Noue P, Bourgeois C, Magistrini M, Palmer E. Centrifugation and addition of glycerol at 22 degrees $\mathrm{C}$ instead of 4 degrees $\mathrm{C}$ improve post-thaw motility and fertility of stallion spermatozoa. Theriogenology 2000;54:907-919.

15. Crocket EC, Graham JK, Bruemmer JE, Squires EL. Effect of cooling of equine spermatozoa before freezing on post-thaw motility: preliminary results.

Theriogenology 2000;55:793-803.

16. Amann RP, Pickett BW. Principles of cryopreservation and a review of stallion spermatozoa. Journal of Equine Veterinary Science 1987;7:145-174.

17. Cochran JD, Amann RP, Froman DP, Pickett BW. Effects of centrifugation, glycerol level, cooling to $5^{\circ} \mathrm{C}$, freezing rate and thawing rate on the post-thaw motility of equine sperm. Theriogenology 1984;22:25-35.

18. Cristanelli MJ, Squires EL, Amann RP, Pickett BW. Fertility of stallion semen processed, frozen and thawed by a new procedure. Theriogenology 1984;22:39-45.

19. Burns PJ, Reasner DS. Computerized analysis of sperm motion: effects of glycerol concentration on the cryopreservation of equine spermatozoa. Journal of Equine Veterinary Science 1995;15:377-380.

20. Vidament M, Daire C, Yvon JM, Doligez P, Bruneau B, Magistrini M, Ecot P. Motility and fertility of stallion semen frozen with glycerol and/or dimethyl formamide. In: Evans MJ, (Ed.) Special Issue, Equine Reproduction VIII, Theriogenology 2002;58:249-251. 
21. Salazar-Valencia F. Embryo recovery rates in mares of the Pasofino Colombiano breed and deep freezing stallion semen in the tropics. Theriogenology 1983;19:146.

22. Muller Z. Practicalities of insemination of mares with deep frozen semen. J. Reprod. Fertil. Suppl 1987;35:121-125.

23. Samper JC, Hellander JC, Crabo BG. Relationship between the fertility of fresh and frozen stallion semen and semen quality. J Reprod Fertil Suppl 1991;44:107-114.

24. Kirk ES, Squires EL, Graham JK. Comparison of in vitro laboratory analyses with the fertility of cryopreserved stallion spermatozoa. Theriogenology 2005;64:14221439.

25. Vidament M, Dupere AM, Julienne P, Evain A, Noue P, Palmer E. Equine frozen semen freezability and fertility-field results. Theriogenology 1997;48:907-917.

26. Brinsko SP, Van Wagner GS, Graham JK, Squires EL. Motility, morphology, and triple stain analysis of fresh, cooled, and frozen-thawed stallion spermatozoa. J Reprod Fertil Suppl 2000;56:111-120.

27. Backman T, Bruemmer JE, Graham JK, Squires EL. Pregnancy rates of mares inseminated with semen cooled for 18 hours and then frozen. J Anim Sci 2004;82:690-694.

28. Varner DD, Vaughan SD, Johnson L. Use of a computerized system for evaluation of equine spermatozoal motility. Am J Vet Res 1991;52:224-230.

29. Evenson DP. Flow cytometry of acridine orange stained sperm is a rapid and practical method for monitoring occupational exposure to genotoxicants. In: Monitoring of Occupational Genotoxicants, M Sorsa, H Norpa (eds). New York, Alan R. Liss, 1986, pp 121-132.

30. Ballachey BE, Miller HL, Jost LK, Evenson DP. Flow cytometry evaluation of testicular and sperm cells obtained from bulls implanted with zeranol. J Anim Sci 1985;63:995-1004.

31. Love CC, Kenney RM. The relationship of increased susceptibility of sperm DNA to denaturation and fertility in the stallion. Theriogenology 1998;52:955-972.

32. Cross NL, Morales, P, Overstreet JW, Hanson FW. Two simple methods for detecting acrosome-reacted human sperm. Gamete Res 1986;15:213-226. 
33. Casey PJ, Hillman RB, Robertson KR, Yudin AI, Liu IKM, Drobnis EZ. Validation of an acrosomal stain for equine sperm that differentiates between living and dead sperm. J Androl 1993;14:289-297.

34. Meyers SA, Liu IKM, Overstreet JW, Vadas S, Drobnis EZ. Zona pellucida binding and zona-induced acrosome reactions in horse spermatozoa: Comparisons between fertile and subfertile stallions. Theriogenology 1996;46:1277-1288.

35. Graham JK, Kunze E, Hammerstedt. Analysis of sperm cell viability, acrosomal integrity, and mitochondrial function using flow cytometry. Biol Reprod 1990;43:5564.

36. SAS User's Guide: Statistics, Version 5. SAS Institute Inc. Cary, North Carolina, U.S.A., 1985.

37. Douglas-Hamilton DH, Osol R, Osol G, Driscooll D, Noble H. A field study of the fertility of transported equine semen. Theriogenology 1984;22:291-304.

38. Francl AT, Amann RP, Squires EL, Pickett BW. Motility and fertility of equine spermatozoa in a milk extender after 12 or $24 \mathrm{~h}$ at $20^{\circ} \mathrm{C}$. Theriogenology 1987;27:517-525.

39. Douglas-Hamilton DH, Burns PJ, Driscoll DD, Viale KM. Fertility and characteristics of slow-cooled stallion semen. J Reprod Fertil 1987;35(Suppl.):649650 .

40. Varner DD, Blanchard TL, Love CC, Garcia MC, Kenney RM. Effects of cooling rate and storage temperature on equine spermatozoal motility parameters. Theriogenology 1988;29:1043-1053.

41. Squires EL, Amann RP, McKinnon AO, Pickett BW. Fertility of equine spermatozoa cooled to 5 or $20{ }^{\circ} \mathrm{C}$. Proc Inter Congress Anim Reprod 1988;3:297299.

42. Varner DD, Blanchard TL, Meyers PJ, Meyers SA. Fertilizing capacity of equine spermatozoa stored for 24 hours at 5 or $20^{\circ} \mathrm{C}$. Theriogenology 1989;32:515525.

43. Magistrini M, Couty I, Palmer E. Interactions between sperm packaging, gas environment, temperature and diluent on fresh stallion sperm survival. Acta Vet Scand 1992;88(Suppl.):97-110. 
44. Moran DM, Jasko DJ, Squires EL, Amann RP. Determination of temperature and cooling rate which induce cold shock in stallion spermatozoa. Theriogenology 1992;38:999-1012.

45. Heiskanen ML, Huhtinen M, Pirhonen A, Mäeenpäa PH. Insemination results with slow-cooled stallion semen stored for 70 or $80 \mathrm{~h}$. Theriogenology 1994;42:1043-1051.

46. Katila T, Combes GB, Varner DD, Blanchard TL. Comparison of three containers used for the trasport of cooled stallion semen. Theriogenology 1997;48:1085-1092.

47. Batellier F, Duchamp G, Vidament M, Arnaud G, Palmer E, Magistrini M. Delayed insemination is successful with a new extender for storing fresh equine semen at $15{ }^{\circ} \mathrm{C}$ under aerobic conditions. Theriogenology 1998;50:229-236.

48. Brinsko SP, Rowan KR, Varner DD, Blanchard TL. Effects of transport container and ambient storage temperature on motion characteristics of equine spermatozoa. Theriogenology 2000;53:1641-1655.

49. Batellier F, Vidament M, Fauquant J, Duchamp G, Arnaud G, Yvon JM, Magistrini M. Advances in cooled semen technology. Anim Reprod Sci 2001;68:181-190.

50. Chanavat E, Vidament M, Defoin L, Duchamp G, Levillain N, Tyon JM, Le Vern Y, Derboeuf D, Magistrini M. Effect of storage and temperature on in vitro stallion sperm parameters and fertility rate. Anim Reprod Sci 2005;89:318-321.

51. Holt WV, North RD. Partially irreversible cold-induced lipid phase transitions in mammalian sperm plasma membrane domains: freeze-fracture study. J Exp Zool 1984;230:473-483.

52. De Leeuw FE, Chen H-C, Colenbrander B, Verkleij AJ. Cold-induced Ultrastructural changes in bull and boar sperm plasma membranes. Cryobiology 1990;27:171-183.

53. Aurich C. Factors affecting the plasma membrane function of cooled-stored stallion spermatozoa. Anim Reprod Sci 2005;89:65-75. 
54. Devireddy RV, Swanlund DJ, Alqhamdi AS, Duoos LA, Troedsson MH, Bischof JC, Robertes KP. Measured effect of collection and cooling conditions on the motility and the water transport parameters at subzero temperatures of equine spermatozoa. Reproduction 2002;124:643-648.

55. Watson PF, Plummer JM, Allen WE, Quantitative assessment of membrane damage in cold-shocked spermatozoa of stallions. J Reprod Fertil Suppl 1987;35:651-653.

56. Woolley DM, Richardson DW. Ultrastructural injury to human spermatozoa after freezing and thawing. Journal of Reproduction and Fertility 1978;53:389-394.

57. Jones RC, Stewart DL. The effects of cooling to 5 degrees $C$ and freezing and thawing on the ultrastructure of bull spermatozoa. Journal of Reproduction and Fertility 1979;56:233-238.

58. Fiser PS, Fairfull RW. Combined effect of glycerol concentration and cooling velocity on motility and acrosomal integrity of boar spermatozoa frozen in $0.5 \mathrm{ml}$ straws. Molecular Reproduction and Development 1990;25:123-129.

59. Pettitt MJ, Buhr MM. Extender components and surfactants affect boar sperm function and membrane behavior during cryopreservation. J Androl 1998;19:736-746. 


\section{VITA}

Name:

University Address:

Email Address:

Educational Background:
Jose L. Salazar

Department of Large Animal Clinical Sciences

College of Veterinary Medicine and Biomedical Sciences

Texas A\&M University

College Station, Texas 77843-4475

jlsalazar@cvm.tamu.edu

B.S., Animal Science, Texas A\&M University

College Station, 2004

M.S., Veterinary Medicine, Texas A\&M University College Station, 2009 